Portland State University

PDXScholar

Spring 6-18-2013

\title{
Baldwin I of Jerusalem: Defender of the Latin Kingdom of Jerusalem
}

John Francis Lowe

Portland State University

Follow this and additional works at: https://pdxscholar.library.pdx.edu/open_access_etds

Part of the History of Christianity Commons, Medieval History Commons, and the Medieval Studies Commons

Let us know how access to this document benefits you.

\section{Recommended Citation}

Lowe, John Francis, "Baldwin I of Jerusalem: Defender of the Latin Kingdom of Jerusalem" (2013). Dissertations and Theses. Paper 1029.

https://doi.org/10.15760/etd.1029

This Thesis is brought to you for free and open access. It has been accepted for inclusion in Dissertations and Theses by an authorized administrator of PDXScholar. Please contact us if we can make this document more accessible: pdxscholar@pdx.edu. 
Baldwin I of Jerusalem: Defender of the Latin Kingdom of Jerusalem

by

John Francis Lowe

A thesis submitted in partial fulfillment

of the requirements for the degree of

\author{
Master of Arts \\ in \\ History \\ Thesis Committee: \\ John Ott, Chair \\ Thomas Luckett \\ Brian Turner \\ Anne McClanan
}

Portland State University

2013 
(C) 2013 John Francis Lowe 
Abstract

The reign of King Baldwin I (1100-1118) has thus far received little noteworthy attention by historians as the important pivotal period following the First Crusade conquest of Jerusalem in 1099. The two decades of his rule marked the extension of Latin conquests in the east, most notably by the conquest of the important coastal cities of Arsulf, Acre, Caesarea, Beirut and Sidon. These vital ports for the early Latin Kingdom of Jerusalem provided outlets to the sea for commerce, as well as safe harbors for incoming assistance from the west. Further, Baldwin led in the establishment of strong secular control over ecclesiastical authorities, and provided a model of administration for subsequent monarchs to follow until the loss of the kingdom in 1187.

Baldwin's contributions to these developments are presented here in a bibliographical framework to illustrate both his important place in crusader historiography, as well as to gauge the significance of his memory in contemporary literature as a second Joshua archetype. The conquest of Jerusalem and the decades that followed were extraordinarily perilous for the western "colonial" transplants, and thus a Biblical precedent was sought as an explanation to the success of the crusaders. This thesis argues that Fulcher of Chartres, the chaplain and primary contemporary biographer of Baldwin I, saw a parallel with the Biblical figure of Joshua as beneficial to posterity. By the establishment of Baldwin's memory in such a context, Fulcher of Chartres encouraged further western support for the Latin Kingdom, and reveals the important trials that faced Jerusalem's first Latin king. 
For the best of parents, Trials they went through,

To an ardent mentor, Inspired and true,

For a son beloved, Lifter of my blues,

To my greatest blessing, Love, what would I be without you? 
Table of Contents

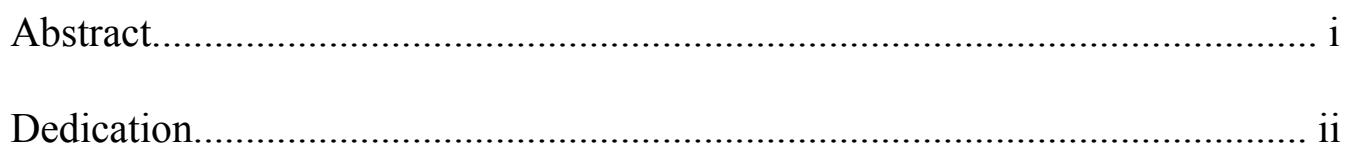

Abbreviations........................................................................................

Chapter 1

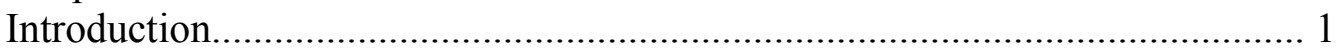

Chapter 2

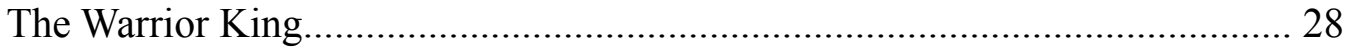

Chapter 3

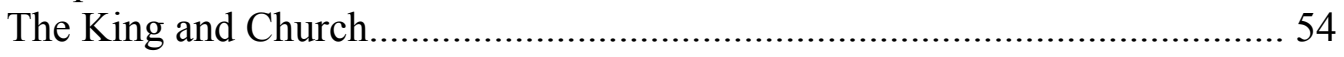

Chapter 4

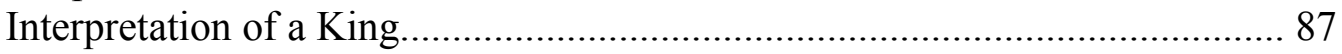

Chapter 5

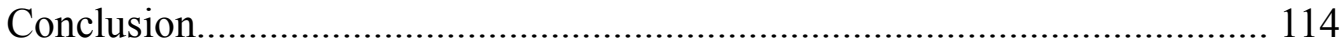

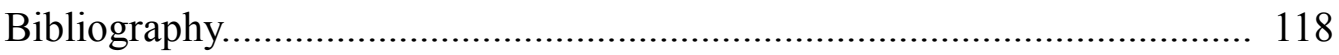


Abbreviations

AA - Albert of Aachen, Historia Ierosolimitana: History of the Journey to Jerusalem.

FC - Fulcher of Chartres, A History of the Expedition to Jerusalem.

GN - Guibert of Nogent, The Deeds of God Through the Franks.

RC - Ralph of Caen, Gesta Tancredi.

RHC Oc. - Recueil des Historiens des Croisades, Historiens Occidentaux. Vol. 4

RR - Robert of Reims, Robert the Monk's History of the First Crusade: Historia Iherosolimitana.

WT - William of Tyre, A History of Deeds Done Beyond the Sea. 
Chapter 1 - Introduction

Of all the colorful figures who embarked on the event later called the First Crusade, Baldwin of Boulogne (1058-1118) was one of the most significant. This was not only because of his role as a crusader who remained in Palestine after many of his fellow Europeans went home, but because he attempted over the course of two decades to consolidate the gains the Frankish, Norman, and German armies had made in the heart of Turkish and Arab-ruled territory within Syria and Palestine. That he achieved great success in the prosecution of these endeavors had lasting consequences on the nature and survival of the Latin Kingdom of Jerusalem. Baldwin established a framework for strong rule and expanded the royal domain for his successors. The absence of a comprehensive modern scholarly biography of this first king of Jerusalem is thus extraordinary, and contributing one constitutes one of the primary aims of this thesis. Like a second Joshua - a comparison made by his biographer and contemporary, Fulcher of Chartres - Baldwin I saved the gains made by the First Crusade and led the Latins in a series of military victories that provided for the kingdom's survival.

In Baldwin, the historian finds a man typical of his age, and yet one who stands out in some specific ways. He was both an ardent warrior of the aristocracy, as well as a literate administrator fully familiar with the politics of the church. His rise from an unentitled, landless third son of his father, to count of Edessa and finally to king of Jerusalem, typifies the meteoric possibilities not only available to ambitious individuals during the crusade, but particular to the wider social changes of the late eleventh century. Stabilizing governments under more powerful monarchs and the increasing 
power of the Church as a major political player began to assist and yet alarm the older established nobility. The conquest and consolidation of England under William the Conqueror in 1066 demonstrated the growing power to be found in the northern lordships of France and Flanders. The dukes and barons around the French and German kings were at the height of their power. However, at the same time, lesser knights and castellans were asserting their perceived rights and demanding their place among the landed aristocracy, with all the powers and possessions pertaining to established nobles. ${ }^{1}$ Increasing civic order, brought about by centralizing governments and written laws, allowed more and more people the latitude to question the legality and justification of power held by the few, and led to internal strife as each succeeding generation sought to establish itself, often at the expense of its forerunners. These are some of the features of the "crisis" of the twelfth century that Thomas Bisson covers so well in his book by the same title. ${ }^{2}$ Baldwin came from this dynamic generation, and well understood its ambitions, dreams, and fears.

To the medieval lord, the landscape of Europe was changing as well. There were adventures to be had, and a Muslim enemy to fight, a force that rivaled Christian dominance in Europe and increased the papal support of violence towards the Islamic world in the middle of the eleventh century. ${ }^{3}$ Militarily talented, adaptable, and learned, the Islamic faithful had formed an aggressive counter empire to that of the ancient

\footnotetext{
$1-26$.

${ }^{1}$ Christopher Tyerman, God's War: A New History of the Crusades (Cambridge: Belknap Press),

2 Thomas Bisson, The Crisis of the Twelfth Century: Power, Lordship, and the Origins of European Government (Princeton: Princeton University Press, 2009). A monumental work evaluating the radical political changes in Europe during the same period in which the Latin Kingdom tenaciously clings to a concept of feudal overlordship, holding out as a frontier kingdom and looking to the past as an answer for the future.

${ }^{3}$ Matthew Gabriele, An Empire of Memory: The Legend of Charlemagne, the Franks, and Jerusalem before the First Crusade (Oxford: Oxford University Press, 2011), 143-157.
} 
Romans in the Mediterranean basin. At least that was the perspective of western Europeans. ${ }^{4}$ Popular Christian images of Muslim foes diametrically opposed to Christianity had begun to take on a fantastical element, involving copious amounts of lore and popular stories. An often quoted scene from chroniclers of the period depicted the horrific torture of Christian pilgrims being tied to a stake by their own intestines, only to be whipped until they killed themselves by their flailing. ${ }^{5}$ Lines between Christians and Muslims were being drawn as a means of identifying religious values and beliefs, Christian from non-Christian, the Chosen people from the damned. These constitute certain attributes of what R. I Moore calls a persecuting society. ${ }^{6}$

These assumption about medieval French and German society, that of developing an understanding of a "common" enemy in the form of the Moors in Iberia and North Africa, and the Muslims of the east, has been challenged by authors like Marcus Bull. Although the Spanish kingdoms were encouraged directly in a kind of border struggle with Muslim taifa kingdoms, being direct neighbors with their Muslim counterparts of Al-Andalus, the notion that northern Europe was aware of religious strife is questioned in Bull's widely cited work, Knightly Piety and Lay Response to the First Crusade. Bull argues that the Peace of God preached in France and the semi-religious wars in Spain were not motivators of significance to the first pilgrims of the crusades. Rather the spontaneous acclamation that greeted Urban II at Clermont was based to no little degree,

\footnotetext{
4 Jonathan Riley-Smith, Crusades, Christianity, and Islam (New York: Columbia University Press, 2008), 14-22.

5 Robert of Reims, Roberts the Monk's History of the First Crusade: Historia Iherosolimitana, trans. Carol Sweetenham (Aldershot: Ashgate Publishing, 2006), 79-80.

6 R.I. Moore, The Formation of a Persecuting Society: Power and Deviance in Western Europe, 950-1250 (Oxford: Blackwell Publishers, 1987). Moore identifies the emergence of a persecuting society as tied specifically to established governmental, judicial, and social institutions. He does not give sole credit to ecclesiastical institutions, but demonstrates a growing increase of violence directed against individuals and groups that emerges in the eleventh century.
} 
Bull argues, on the form of his argument and the knightly audience's understanding of the redemptive qualities that rewarded pilgrimage. ${ }^{7}$ However limited European knowledge of the Muslim world may have been, the sermon given at Clermont on November $11^{\text {th }}$, 1095, quickly informed those who attended of the 'nature' of the enemy.

The sudden restriction of Jerusalem as a place of Christian worship under the Seljik Turks, caused concern in western Europe. Pilgrimages to the east were incredibly popular, and many a notable figure was to be found making the effort in the early eleventh century, Fulk Nerra Count of Anjou being just one well known celebrity pilgrim. The closure of Jerusalem was a serious blow to Christian Europe, and perceived to be a clear sign of the end of times. ${ }^{8}$ In some apocalyptic visions prevalent c. 1100 , the end times were fast approaching, and this was not an altogether frightening thought.

Unveiling before their very eyes was the apocalyptic world of Revelation. The Antichrist was sitting in the Holy of Holies and had closed the doors of the earthly Jerusalem, and the final days had come when those faithful to Christ were being called to fight.

Doubtless civilization appeared to be reaching it nadir according to Christian scholars. Implicit in this world view was the fact that New Heaven and New Earth were on their way at last. Old Testament prophecy was being fulfilled, and to those anxious to see the return of Christ, only one place would do for the front row seat: Jerusalem.

\footnotetext{
${ }^{7}$ Marcus Bull, Knightly Piety and the Lay Response to the First Crusade: the Limousin and Gascony c.970-c.1130 (Oxford: Oxford University Press, 1993). This monograph centers on the charter evidence found in the Limoges and Gascony regions of southern France, and is inherently weak in standing as evidence for all other parts of France. However, the concepts that Bull raises in this work are very important for understanding the disposition of Frankish society, the influence of the local ecclesiastical authority in rousing continued support for the First Crusade, and developing the idea that crusaders saw their role as an extension of a monastic tradition of denial of self and expunging of sins.

8 Jay Rubenstein, Armies of Heaven: the First Crusade and the Quest for Apocalypse (New York: Basic Books, 2011). Rubenstein's recent work provides a focused study on the nature of end times doctrine woven into the interpretation of events happening at the end of the tenth century, looking to the millennial kingdom and the return of Christ.
} 
More immediately, the emperor of Byzantium, Alexius I (1081-1118), had requested help from the papacy in 1095 for support against the Seljuk Turks. This led to the assumption by westerners that the emperor would reward anyone that came east to fight. In addition it was believed that Alexis was ultimately preparing to march to war as the leader of the spiritually and martially minded westerners. The hopes of the Latin west and Greek east thus appeared to coincide. The image of a glorious host of men on pilgrimage in the company of the Greeks was the ultimate adventure of the era, and one not to be missed. Many Spanish knights had to be restrained by Urban II himself, citing their own direct war with the Muslim world back home on the Spanish frontier. It has to be said that in this light, the armed pilgrimage to Jerusalem did not appear on the face of it to be an unachievable endeavor, just arduous, which fit the penitential character of the act of crusading. ${ }^{9}$

Baldwin of Boulogne was born into this period and faced the challenge of crusade as a young man, one with very little to lose in his homeland and much to gain. What eventually fell to him in the end was the responsibility of ruling the Latin Kingdom of Jerusalem, a position that he gladly accepted, but which was full of hard work for the remainder of his life. Though not present at the siege of Jerusalem in July 1099, and having failed to take part in the grueling siege of Antioch (in October 1097-June 1098), Baldwin nevertheless took on the job of consolidating and protecting the gains made by the crusaders centered around Jerusalem. His success was not due to the martial power of the Latin Kingdom, which lacked manpower throughout his eighteen years of rule. Nor was it owing to the support of the Church, for in fact he often found great hindrances in

9 Hans Eberhard Mayer, The Crusades, trans. John Gillingham (London: Oxford University Press, 1972), 1-8. 
the clergy that remained in the holy land after the crusade, as well as those that came in the post-conquest years. Neither was the answer to his success the additional aid that came from all corners of Europe, from Norway to Genoa. While all of these factors contributed to Baldwin's effective defense of Christian interests in Palestine, ultimately it was Baldwin himself who made a series of critical decisions over the nearly two decades of his rule, which set the stage for those who eventually followed him on the throne. Baldwin's policy of diplomatic and, at times, forceful negotiations led to the success of the Latin Kingdom of Jerusalem. At the time of his death it had almost reached the maximum extent of its size for the next sixty-nine years. The kingdom would extend a little further with the acquisition of Tyre in 1124 and the eventual conquest of Ascalon in 1153, but effectively did not grow after his reign. Baldwin's conquests during this eighteen-year period (with few reversals), went far towards stabilizing the gains of the First Crusade. Baldwin's legacy of leaving a substantially larger kingdom than he inherited to subsequent kings, is a point that modern scholars have not highlighted thoroughly.

Ultimately the historian of the Latin Kingdom must come to grips with the figure of Baldwin of Boulogne. He was an effective leader and administrator, and time would demonstrate that he had the skill and the experience required to lead, along with a little luck. What cannot be escaped is the fact that Baldwin appeared from the beginning of his rule to have had a vision for his kingdom and a blueprint for all his actions as a consolidator and survivalist, forged from the four years of crusader warfare that led up to his coronation. That he was the only First Crusade leader capable of directing the well- 
being of the kingdom at the time is beyond doubt, and that he did so until his death was no accident. Indeed, as Fulcher of Chartres remarked, Baldwin appeared to have been chosen as a new Joshua for the Christian people taking up residence in a promised land. Like Joshua, he took over the role of leadership, dispensed lands to the Franks as he gained them, and proved to be an effective military commander, all of which made it seem obvious to at least one clerical witness that a hero of biblical proportions stood among them.

\section{The Primary Sources}

For the study of Baldwin's reign and actions from the beginning of the crusade to the end of his life, no other writer has had more influence on his memory than Fulcher of Chartres, the chaplain that joined Baldwin shortly before his elevation to count of Edessa in 1097. An interesting man in his own right, Fulcher has the distinction of being a key writer for the history of crusader Palestine following the capture of Jerusalem, the lordship of Godfrey of Bouillon (1099-1100), the rule of Baldwin I (1100-1118), and the middle years of Baldwin II's reign (1118-1127). ${ }^{10}$ Living in the Latin Kingdom for almost three decades, Fulcher of Chartres had to reconcile the success of the First Crusade with the constant threat of annihilation that haunted the first few decades of Frankish rule. Though prone to exaggeration and invective against avarice and slothful behavior on the part of the Christian leadership of the Latin Kingdom, Fulcher

\footnotetext{
10 Verena Epp, Fulcher von Chartres. Studien zur Geschichtsschreibung des ersten Kreuzzuges (Düsseldorf: Droste Verlag, 1990). A relatively recent work concerning Fulcher has come out in German by Verena Epp, analyzing the person of the chaplain through his chronicle. In this work she attempts to argue that the most important key for understanding the crusader's thoughts comes from a comparison between his first and final redaction of the manuscript.
} 
nevertheless presents to modern historians, as he did to medieval ones, an illumitive picture of the events that transpired during his lifetime. ${ }^{11}$

One of the advantages of Fulcher's writing lies in the clarity of his battle accounts. While his estimates of the forces opposing the crusaders are often presented in large round numbers, Fulcher successfully illustrates the desperate nature of the military engagements he and others had witnessed, highlighting the odds against the Christian forces. Though he may come across from his own text as an individual prone to fits of panic, and exhibits some doubtful physical resolve, there is no reason to assume that he completely exaggerates about the size of the enemy forces he saw firsthand. The Muslim rulers of the east were in fact able to field large armies of mercenary soldiers, and a chaplain from Chartres would be easily impressed. It would appear that the large numbers also puts into perspective Fulcher's attempt to simultaneously awe his audience back in Europe by the sheer magnitude of the works of God in destroying vast hordes of enemies, and to showcase the main pillar of his argument for Baldwin's role as a new Joshua, in the position of field commander and military strategist. His purpose was to encourage warriors from the west to come and take part in the battles, not to be scared off by the enormity of the proposition. ${ }^{12}$

Fulcher of Chartres' work was widely read in western Europe, as well as in the Latin Kingdom. An early version of the first book of his three-volume work was available to his audience shortly after its completion in 1101 . This encompassed the

${ }^{11}$ The Crusades: an Encyclopedia, $2^{\text {nd }}$ ed., s. v. "Fulcher."

12 Dana Munro, “A Crusader," Speculum 7, no. 3 (1932): 321-335. Over and over again, Fulcher's benchmark for the severity of military situations, principally involving the defense of the kingdom, can be determined by the presence of the True Cross. He makes note of its presence in battle and on campaign on numerous occasions. This stressed the importance of the relic to him, as well as to the Christian community. 
crusade, its success, and the death of Godfrey of Bouillon. The second book took much more time to develop; it narrates the reign of Baldwin I, which ended in 1118. The third book was still being written when the narrative came to an abrupt halt sometime in the year 1127. Previous to this, in 1124, Fulcher made his final redaction of the work completed to that point. Several other medieval writers, including Albert of Aachen and Guibert of Nogent, knew of Fulcher's work. William of Tyre, who began to compose his history of the Latin Kingdom some thirty years later, also had access to Fulcher's chronicle. This made the chaplain's work accessible to later writers, and establishes him as a primary source for the First Crusade alongside the works of Robert the Monk and Raymond of Aguilers, who both composed early accounts. ${ }^{13}$

From a diplomatic perspective Fulcher gives the modern historian insight into the deals that Baldwin made with allies who aided the king in his conquest of the coastal cities of the Levant. The Genoese and Pisan fleets, and their much needed military backing, feature prominently in the history, as does the aid of the Norwegian crusader, Sigurd I. Additionally, Fulcher tended to see the world in black and white. He viewed the motivation of King Baldwin to have often been the acquisition of money, and as a churchman, Fulcher is roundly critical of any figure in his narrative that seemed to be looking out for his own best interests or self-enrichment. His chronicle displays an obvious disgust with the greed of the Italian allies in regards to the spoils of the coastal towns of Acre and Arsuf, and generally the chaplain does not appear in his work to empathize with the needs of his king to keep the kingdom's treasury solvent. Fulcher notably does not seem to count the cost of military activity in monetary terms, no doubt

\footnotetext{
${ }^{13}$ Christopher Tyerman, The Debate on the Crusades (Manchester: Manchester University Press, 2011), 7-12.
} 
because he personally felt that men should fight for the defense of Jerusalem and the kingdom by the grace of God alone. However, Fulcher's criticism only reveal Baldwin I as a stark realist, capable of ascertaining the needs of the kingdom much better than his biographer. ${ }^{14}$

From the perspective of Baldwin I's struggle with ecclesiastical authority, Fulcher of Chartres usually takes the side of the Church in his tone, but it is evident throughout his interpretation of motives that he favors on the whole the policies of the king to forward the secular interests of the kingdom versus the ecclesiastical. When the opportunity arises to comment on matters that brought Church and state into conflict, such as the ascension of Daimbert of Pisa to the patriarchate of Jerusalem (a man who was notoriously at odds with Baldwin I), Fulcher has very little to say. There are hints of that Fulcher was privy to more information than he reveled about the strife between the Church and the secular authority, understandably from his clerical background. However, he was in favor of unity for the betterment of Christendom with no place for personal ambition. This position required him at times in his work, to suppress conflicts that may have showed to his readers the greater rifts between Outremer leaders. The result was a picture of general harmony that may not have existed in fact. ${ }^{15}$

Finally, Fulcher gives the Frankish perspective on the various Christian sects to be found in Syria and Palestine. He gives the impression that Baldwin I was one of the primary movers in seeking reconciliation with the local Armenians and Syrian Christians, notably with the goal of repopulating Jerusalem, but also in finding a degree of

\footnotetext{
${ }^{14}$ Fulcher of Chartres, A History of the Expedition to Jerusalem 1095-1127 (hereafter FC), trans. Frances Rita Ryan, ed. Harold S. Fink (Knoxville: University of Tennessee Press, 1969), 36-42.

15 FC, 7-17.
} 
reconciliation with the Byzantine Empire through the maintenance of the Greek Orthodox presence in the Holy City. The crusader host that had originally conquered Jerusalem appeared set on a policy of exclusion of all Christian sects other than those following the Roman Church, but Baldwin's reign saw a reversal of that position. Fulcher gives a glimpse of this in regard to the failure of the Easter Fire discussed in chapter three, early in Baldwin's reign, and his rapprochement with the Greek priests that had been excluded from the Holy Sepulcher. While Fulcher maintains a hostility towards the emperor Alexius Comnenus and supports the later campaign of Bohemond, which only ended in 1108 , there is no evidence to suggest that Baldwin I supported open war with the Greeks. It is also true that unlike Bohemond, Baldwin was not contesting with the Byzantine emperor for the suzerainty of his kingdom. ${ }^{16}$

Fulcher of Chartres thus gives a balanced, if somewhat biased, perspective on the events of his lifetime, covering an occupation in Palestine for nearly thirty years before ending his history in 1127, which most historians attribute to his death rather than an end of his interest in the subject. Fulcher would therefore have had time to reevaluate the reign of Baldwin I and later revised some of his earlier writing, but on the whole he gives the king the best praise in regards to his characterization as a new Joshua, a man carrying on the work of his older brother before him. Duke Godfrey had, like a second Moses, brought the new Israelite nation of Franks to the gates of the kingdom. It was his heir Baldwin, who finished the work of conquering the inhabitants of the holy land. Towards the end of his history Fulcher writes the famous and often quoted passage alluding to the fact that the western Europeans had settled into their new homes, forgotten old ties to the

\footnotetext{
${ }^{16} \mathrm{FC}, 37-38$.
} 
west and were asserting new identities, prospering and thriving in the Holy Land. ${ }^{17}$ Though coming late in the chronicle, it would appear that Fulcher had not forgotten the work of Baldwin I in addressing the threats to the new Frankish settlers, and the identification with the prosperous Israelite nation of the Old Testament supports his argument that the first king of Jerusalem was indeed a successful second Joshua.

Second in importance to Fulcher of Chartres for an evaluation of the deeds of Baldwin I, is the extremely detailed history of Albert of Aachen, the composer of the longest contemporary account of the First Crusade. Beginning right after the conquest of Jerusalem in 1099, the composition continued until some time around 1130. Albert's rendition of events benefits from the distance from which he wrote, and his reliance on a larger array of personal accounts brought back and culled from eyewitnesses. Albert did not go on crusade but was forced to stay home by the superior of his church. He did not serve in the entourage of a king, nor follow a noble in the capacity of a chaplain, but this allowed him freer rein when it came to critiquing the performance of individual crusaders. While this method of the armchair historian has the disadvantage of being reliant on the honesty of the men and women returning from their five-year-long ordeal in the Holy Land, it would appear that Albert was very cautious when it came to presenting the facts in his history. Though exposed to the work of Fulcher of Chartres, Albert was able to compose a history that can be compared and contrasted with the eyewitness account of Baldwin's chaplain. ${ }^{18}$

Albert's contribution to the history of the reign of Baldwin I is unique in that, not being a participant himself, Albert seems to approach the various factions at odds in 17 FC, 271-272.

18 The Crusades: an Encyclopedia, $2^{\text {nd }}$ ed., s. v. "Albert of Aachen." 
Palestine with a certain degree of fairness. As Susan Edgington notes in her introduction to the recent edition of Albert of Aachen's work, the author seldom ascribes to a biased position or set policy. This is best seen in that he is not personally invested in the disputes between Christian factions, though a preference for Godfrey of Bouillon and Baldwin of Boulogne is evident in the first part of his work. As to Jews, Muslims, and Byzantines, Albert adopts a more neutral tone and at times can be quite sympathetic to those outside the Christian faith. Thus, Albert of Aachen brings an extensive, if not more academic tone, to his work than Fulcher of Chartres, and presents Baldwin I and his role as king from a remote and not always sympathetic angle. ${ }^{19}$

The third primary source, William, the archbishop of Tyre from 1175-1184, began the composition of his History of the Deeds Done Beyond the Sea in 1167 and did not bring the work to a conclusion until 1183, presumably because of the illness that lead to his death early in the next year. ${ }^{20}$ Having been encouraged to undertake the project by King Amaury (1163-1174) to celebrate the deeds of the Latin kings of Jerusalem, William composed one of the greatest historical records of the medieval period. Trained as a lawyer in canon law and possessing a talent for languages, William of Tyre presents his narrative with the benefit of being an educated churchman with access to classical literature as well as Arabic sources. A. C. Krey goes as far as to say that no Latin writer from the end of the classical period up to the Renaissance can be found to compete with William as an eminent historian. ${ }^{21}$ This was not what he had been trained for, but he took

\footnotetext{
19 Albert of Aachen, Historia Ierosolimitana: History of the Journey to Jerusalem, trans. Susan Edgington (Oxford: Oxford University Press, 2007), xxi-xxxvi.

20 The Crusades: an Encyclopedia, $2^{\text {nd }}$ ed., s. v. "William of Tyre."

21 William of Tyre, A History of Deeds Done Beyond the Sea, trans. Emily Atwater Babcock and A.C. Krey (New York: Octagon Books, 1976), 3-4.
} 
on the task and it is this work that he is known for. Regrettably none of his other works survive, for they would have been of great importance to crusader historians on the development of Islamic rule in the region, as well as insightful about the sources of information available to William in the middle of the twelfth century. ${ }^{22}$

For the study of Baldwin I's reign, William of Tyre offers the advantage of distance from the events he describes, for he began composing the history initially for the benefit of King Amaury of Jerusalem. Amaury was not part of the dynastic line of Bouillon-Boulogne, and thus William could be more critical in his appraisal of earlier kings like Baldwin I. While utilizing the accounts of the First Crusade and its aftermath, such as the works of Fulcher of Chartres and Albert of Aachen, William sifts through the information in a deductive way that harkens back to his judicial training, and from his assessment combined with the events following the year 1127 when Fulcher ceases to write, William is able to look back on the early decades with the benefit of hindsight and the freedom to appraise the results. Thus, in his two books on Baldwin I, William of Tyre presents a historical memory of Baldwin at a date just fifty years removed from his subject. $^{23}$

These three historians present the primary medieval historiography of Baldwin I, establishing the narrative of events and the earliest appraisals of his success as a king; the effectiveness of his policies towards allies and enemies; and ultimately the contributions he made to the preservation of the Latin Kingdom. As will be illustrated in the following chapters, all three establish points of agreement in their private remarks and through their

22 WT, 3-53.

23 Peter W. Edbury and John Gordon Rowe, William of Tyre: Historian of the Latin East (Cambridge: Cambridge University Press, 1988), 32-58. 
interpretation of history, that allow for a conclusion that Baldwin I did indeed fulfill his role as a "second Joshua." He established a permanence to the kingdom through aggressive military expansion and diplomatic maneuvering.

In addition, in order to research the life and activities of Baldwin I of Jerusalem, the historian may also turn to the contemporary missives of other Christian writers and Muslim authors who were composing commentaries on the newcomers into Palestine. Letters written by crusaders are available in translation and give a picture of life for the men and women able to send home their thoughts. Hans Eberhard Mayer has recently published Die Urkunden der lateinischen Könige von Jerusalem, a new scholarly edition of all diplomatic documents of the Latin Kingdom after its conquest. ${ }^{24}$ These documents are limited in the information they give, focusing on the royal acts of bequeathing rights, lands and titles. While these find a place in the present study, Baldwin's voice never truly comes forth in them. Baldwin typically left his mark as all men of action do, namely in their deeds. Thus it is through the accounts of his deeds that Baldwin is best contextualized as a second Joshua figure for the Franks.

\section{Secondary Sources}

Despite the relatively abundant material provided by the primary textual sources, the reign of Baldwin and his role as secular, martial, and to some degree spiritual leader of the kingdom has received comparatively little close analysis or interpretation. Recently, Alan V. Murray in his prosopographical work entitled The Crusader Kingdom of Jerusalem: A Dynastic History 1099-1125, attempted to address this gap in the

${ }^{24}$ Hans Eberhard Mayer and Jean Richard, eds., Die Urkunden der lateinischen Könige von Jerusalem, 4 vols. (Hannover: Hahnsche Buchhandlung, 2011). 
scholarship by illustrating the background and activities of the first legitimate rulers of Jerusalem. This work, somewhat brief and considering the reign of three rulers, highlights the activities of Baldwin in consolidating the Latin kingdom of Jerusalem, but fails to interpret much of his reign either through extensive political and military maneuvering, or to look at Baldwin's character as represented by the chronicles. In his defense, Murray was attempting to write a short prosopographical history, placing the activities of the Bouillon-Boulogne dynasty into perspective, and did not single out Baldwin for a biographical work, but this recent addition to our understanding of this noble family is by far the only piece of recent scholarship to deal with any degree of thoroughness with the first Latin king of Jerusalem. ${ }^{25}$

Of the several tertiary studies, the works of Joshua Prawer, Bernard Hamilton, Jonathan Riley-Smith, Norman Housley, Marcus Bull, Christopher Tyerman, and Ronnie Ellenblum are to be mentioned specifically for what they have to say on the condition and institutions of the crusader states, the crusaders themselves, the ecclesiastical authorities in the holy land, and the archaeological evidence that shapes our understanding of the world of the Latin Kingdom. The studies of these scholars bring into perspective the problems that Baldwin faced upon arrival in Jerusalem, and the prosecution of his rule through logical choices that can be understood through an evaluation of the evidence. Jonathan Riley-Smith introduced in his work on the First Crusaders a valuable catalog of all the crusaders known by name to scholars in 1997 . This study illuminates the picture of connections between crusaders, highlighting at the same time aspects of political

\footnotetext{
25 Alan V. Murray, The Crusader Kingdom of Jerusalem: A Dynastic History 1099-1125 (Oxford : Prosopographica et Genealogia, 2000); Paul Rudolf Grindler, Graf Balduin I. von Edessa (Halle an der Saale, 1901); focused on the career of Baldwin in Edessa alone; and Alfred Wolff, König Balduin I, von Jerusalem (Königsberg, 1884), was a short dissertation on the king.
} 
alliances that formed and possible causes for contention between the nobles. ${ }^{26}$ Joshua Prawer's study of the crusaders in the holy land and the establishment of their kingdom, its civic functions, and what he believed to be European colonization are invaluable to understanding the kingdom Baldwin ruled. ${ }^{27}$ Ronnie Ellenblum, a current scholar in the field, modifies some of Prawer's earlier hypotheses on the rule of the Latin Kingdom, and thus is essential for comparison. ${ }^{28}$

Bernard Hamilton's work on the secular church in the Latin Kingdom traces out the establishment of the ecclesiastical authority propagated among the crusader settlers, and looks critically at the quality of spiritual leadership available to Baldwin, demonstrating who was suitable for office, as well as analyzing the controversial patriarchate of Jerusalem. ${ }^{29}$ Marcus Bull's earlier mentioned work on Knightly Piety, plays into the topic of priestly influence on the nobility and men-at-arms, and remains one of the most highly cited works in crusader studies.

Christopher Tyerman's masterpiece, God's War: A New History of the Crusades, fights in its own way to reassert the human element of the crusades, stripping away as much as possible the speculative and biased notions that a modern audience directs towards the past. Such an attempt is rewarded by insights into the mind-sets of the historical figures themselves, and puts the long history of crusading into a new perspective. ${ }^{30}$

\footnotetext{
26 Jonathan Riley-Smith, The First Crusaders 1095-1131 (Cambridge: Cambridge University Press, 1997).

27 Joshua Prawer, Crusader Institutions (Oxford: Oxford University Press, 1980), and The Crusader's Kingdom: European Colonialism in the Middle Ages (New York: Praeger Publishers, 1972).

28 Ronnie Ellenblum, Frankish Rural Settlement in the Latin Kingdom of Jerusalem (Cambridge: Cambridge University Press, 1998).

29 Bernard Hamilton, The Latin Church in the Crusader State: The Secular Church (London: Variorum Publications, 1980).

30 Tyerman, God's War.
} 
Finally, Norman Housley provides a comprehensive study on the experience of crusading in his recent work, taking a moderate view of the impulses and exterior drives that led so many men and women to take the cross. This work is somewhat more analytical of motivation, evaluating medieval society and people in their own setting, treating them as human beings with dreams and fears and bringing the written records to life in a way that allows for some closer interpretation. ${ }^{31}$

\section{Short Background History}

Baldwin of Boulogne was born sometime around 1058 to Eustace II of Boulogne and Ida of Lorraine as a third son, coming after his brothers Eustace III and Godfrey. Thus he was born without an expectation of inheriting lands from his father or mother, a reality many sons of the European nobility confronted in the early twelfth century. ${ }^{32}$ Baldwin's father found him a career early on in the church, winning him prebends in the churches of Reims, Cambrai, and Liège, the latter ecclesiastical institution already under the influence of Baldwin's family. The bishop of Liège was a kinsman of Godfrey, and thus related to Baldwin. This connection aided the youngest brother, and it can be conjectured that Baldwin learned to read and to write thanks to his early affiliation with the church. What is unknown with certainty, is the level of church law that he was exposed to at this time, and whether or not he was schooled in the rudimentary elements of rhetoric and logic. However, at some point undefined by William of Tyre, who likewise seems uncertain, Baldwin abandoned the life of a churchman to pick up the

\footnotetext{
31 Norman Housley, Fighting for the Cross: Crusading to the Holy Land (London: Yale University Press, 2008).

32 Murray, Dynastic, 30-31.
} 
sword in the service of his brother Godfrey as a military man, subsequently marrying an English woman by the name of Godehilde. This marriage brought him estate lands not only in England, but in Flanders as well. ${ }^{33}$

Baldwin of Boulogne found a sudden change of fortune when Pope Urban II gave his sermon at Clermont in late November of 1095, calling on all capable warriors to go to the rescue of Jerusalem. This call to arms launched a massive exodus of military men to a relatively distant and extremely hostile location, a trip from which most would not return. Godfrey of Bouillon, who had been fighting with local magnates to maintain his inheritance in Lorraine, seems at this point to have given up much of his temporal fight and eyed the crusade as a means of starting over. The chance at adventure and spiritual rewards served as an extra incentive. Selling off much of his land, Godfrey took off on what was perceived to be a pilgrimage of great spiritual value. ${ }^{34} \mathrm{He}$ was accompanied by his older brother Eustace III and younger brother Baldwin. The latter had the most to gain from such a venture, though he too had to alienate the dowry lands brought by his wife to pay for the pilgrimage. ${ }^{35}$

Baldwin of Boulogne receives very little attention in the earlier parts of the crusade narratives. He does not give any speeches to distinguish himself, and his activities mirror or work in tandem with the wishes of Godfrey his brother. While it is true that perhaps he defered to his older and wealthier brother, no sense of Baldwin's personality shines through the narratives. On a couple of occasions a difference of

\footnotetext{
33 Malcolm Barber, The Crusader States (London: Yale University Press, 2012), 15-16. Barber presents the interesting idea that Baldwin's prebends were common enough, but contrary to cannon law. The reforming church leadership may have put pressure on him and his family to give up this source of income, leading ultimately to his first marriage to Godehilde. WT, 415.

34 Housley, Cross, 47-53.

35 Murray, Dynastic, 34-35.
} 
opinion emerges between the two men, such as Godfrey's decision to give King Coleman of Hungary hostages for the good behavior of the crusaders passing through his lands. Baldwin disputed with his brother vehemently, according to Albert of Aachen, but was eventually prevailed upon to agree for the good of the crusaders and their joint cause. ${ }^{36}$ Whether this scenario was used by Albert to depict a certain stubbornness about Baldwin's character, fear for his person, or as a foil to highlight Godfrey's piety, remains uncertain. It may be that Baldwin and his wife Godehilde, who were given over to King Coleman, a distant relative, had ample reason to doubt the ability of the massive army to control its members. This could cause the forfeiture of the lives of the hostages, but the passage does reveal that Baldwin was of some importance even at the onset of the campaign, not entirely dependent on or within the complete control of his older siblings.

How the brothers Godfrey and Baldwin dealt with the demands of Alexius I of Byzantium was somewhat mixed. Godfrey was at first reluctant, which led to armed conflict between his forces and the emperor's. Yet Fulcher tells us nothing of the matter. Uninterested in the debates over whether to swear fealty to the emperor or retain their autonomy, which many of the crusader leaders wanted, Fulcher of Chartres passes right over the contentions between crusaders and Byzantines with so many simple pen strokes, merely folding Baldwin's decisions in with Godfrey's to accept the emperor's oath. ${ }^{37}$ On the other hand, Albert of Aachen gives a very detailed account of the power struggle between the duke of Lorraine and the Roman emperor, in which at times Baldwin suddenly emerges from the events in martial glory. There is a certain degree of confidence in Baldwin that Godfrey displays, sending his brother with 500 armored 
knights to ward off a frontal assault by the emperor's men at a bridge between the crusader camp and the city, near the imperial palaces on the shores of the straits. In this episode Baldwin is attacked by a strong force of Turcopoles, but he turns them back after a long engagement. ${ }^{38}$

Following the transportation of the main crusader hosts to the Turkish-ruled territory across the Bosporus, Godfrey and his brothers proceeded through Turkish and Byzantine contested territory to the city of Nicaea. When this city fell after a protracted siege, the westerners were made to understand, by a shady deal on the part of the Nicaean guard and the Byzantines who received their surrender, that the Greeks were primarily interested in the restoration of the lands they had once dominated. Jerusalem was not high on the agenda of the emperor, and for better or worse the crusader hosts proceeded forward without much more than an honor guard from the Greek Empire. ${ }^{39}$

The decision of Baldwin to break off from the main body of the army and to pursue his own profit in the interior of Syria was not critiqued by Fulcher of Chartres, who accompanied Baldwin as his chaplain from this point on. ${ }^{40}$ To say that Baldwin was potentially looking for a chance to carve out a small fiefdom of his own is not disputed by any modern scholar, but there is room to argue that he and Tancred were involved in a loose form of reconnaissance for the main crusading host. Both men were possibly sent out by their older relatives to stake claims to new lands, and to augment their respective

38 AA, 76-81. "Sed Baldwinus inmobilis et insuperabilis ab omni illorum assultu in loco constituto perstitit, donec a mane usque ad uesperum populo trans pontem ante urbis menia relato, et castris positis hospitato, eosdem Turcopolos a portis egressos, et populum inpugnantem cum quingentis loricatis fortiter incurrit, et utrimque grauiter commissio prelio plurimi hinc et hinc ceciderunt, plurimi equi Francorum sagittis interierunt. Sed ad ultimum Baldwinus preualens, milites hos imperatoris grauatos ac fugitiuos in portas remisit, campum et uictoriam potenter obtinuit."

39 Housley, Cross, 4-5.

40 FC, 89. 
factions, Lotharingian and Sicilian. ${ }^{41}$ The Gesta Tancredi and the account given by Albert of Aachen depict two minor lords disputing over captured territories. The example presented is the dispute over the city of Tarsus of the region of Cilicia. Though rival claimants, Baldwin and Tancred were accompanied by men that were not necessarily in their pay, and thus their respective strength may have been comparable. ${ }^{42}$ It is quite possible that both were followed by those who felt that their fortunes were best served in doing so.

In the episodes leading up to the eventual lordship of Edessa, Baldwin committed a series of actions that would later cause contemporary as well as modern historians to question his complicity in morally reprehensible behavior. The first was the death of men loyal to Tancred's cause outside of Tarsus. Tancred had taken the city before Baldwin arrived, and had nearly gone to war with the latter's force when he approached. Upon recognizing each other, peace was restored, but Baldwin demanded not just a share in the conquered city but its ownership. In the dispute that broke out, Baldwin kicked Tancred's men outside the city walls and would not let them return. Tancred left, but a force of knights sent by Bohemond arrived to bolster his nephew's position. Baldwin refused to allow them into the city. Meanwhile, the inhabitants of the city made an escape in the middle of the night. Utilizing the opportunity, they slew many of Tancred's forces outside the walls while making good their escape. ${ }^{43}$

The reason for the vengeful killing perpetrated by the fleeing citizens never comes into serious question by Albert of Aachen, for obvious reasons. Atrocities of war were

41 Tyerman, God's War, 130-132.

42 Ralph of Caen, Gesta Tancredi, trans. Bernard S. Bachrach and David S. Bachrach (Aldershot: Ashgate Publishing, 2005), 60-70.

43 WT, 182-183. 
common. Rather it was Baldwin's choice to leave fellow Christians outside the protective walls of the city that came under fire. ${ }^{44}$ It must be pointed out that earlier it was Baldwin who instigated the conflict between his and Tancred's forces, resulting in other Christian deaths. Baldwin was solely to blame. For a brief moment, his life appears to have been in some danger. His apparent greed for lordship of the city and the expulsion of Tancred's men was rightly seen as a crime against the Norman forces. Apologies and promises of good faith in the future got him out of the situation he found himself in, but never again did Baldwin allow events to corner him into a decision in which his interests were so visibly and violently apposed to those of another Latin nobleman. ${ }^{45}$ It is clear that he began to learn something of greater delicacy in diplomacy during this episode. This is why one may argue that the events leading to his succession to the lordship of Edessa, namely the death of the Armenian ruler Thorus I, are a little harder to scrutinize. Baldwin was being careful on his next acquisition.

Fulcher of Chartres, Albert of Aachen, and William of Tyre all give slightly different accounts of Baldwin's activities at Edessa, but they agree on all the major points, which tends to lend credence to the argument that Baldwin tried to shape the memory of the event a little himself. When he arrived in the vicinity of Edessa, the citizens urged their ruler in no uncertain terms that they wanted this strong field commander and Christian leader to be on their side. Rather than turn over completely the reigns of power to Baldwin, Thorus I went through a ritual of adoption, bringing Baldwin alongside him in power. However the citizens turned on their prince, and there was a conspiracy of which Baldwin was apparently informed. The chronicle accounts suggest that Baldwin 44 AA, 155-159.

45 WT, 183-184. 
did not raise a hand against his adoptive father Thorus, but that he also did little to prevent the violence threatened by the people of Edessa against him. None of the sources explicitly suggest that Baldwin fueled the issue and stirred up rebellion, but there does seem to be a single beneficiary to the whole situation; with Thorus removed, Baldwin ruled Edessa alone and supreme. ${ }^{46}$

There is no doubt that the people of Edessa felt they had made the right choice in selecting Baldwin, who acted swiftly in threatening the city of Samosata. This city, nominally under the influence of Edessa, had rebelled and was under the control of a man named Balduk. The cost to risk factor of besieging the city was apparently too great, and it would seem that Baldwin had gained a considerable amount of money from his adoptive father, for he eventually bought Balduk off and brought Samosata back under the influence of Edessa again. In addition he laid siege to another nearby city, Seruj, and took it by storm. ${ }^{47}$ At this time, Baldwin married again. On this occasion it was to an Armenian noble's daughter, Arda. This marriage brought additional support by way of incorporating Baldwin into the Armenian nobility and dynastic families, but it also secured his finances in the form of a dowry that was much needed at this time. ${ }^{48}$ These were not his only successes. Baldwin was clearly effective in his new administrative role over the first crusader principality to be carved out in the east, in that he was able to not only send much needed supplies from his territory to his brother Godfrey outside the walls of Antioch in the summer of $1098,{ }^{49}$ but was also able to hold up for a short time the army of Kerbogha of Mosul, who allowed himself to be diverted by the audacious

46 FC, 91-92; AA, 169-177; WT, 189-194.

47 WT, 192-195.

48 AA, 1187-189.

49 AA, 263-265. 
Christians who had taken control of Edessa. The sources do not give us much insight into the rebuilding of walls or placement of new defenses, but the outcome appears to speak for Baldwin's success in holding his own, because Kerbogha began to worry over the amount of time that had elapsed since his siege of Edessa, and finally continued towards Antioch, which was in great danger of falling to the crusaders. ${ }^{50}$

Baldwin's activities in the immediate aftermath of the fall of Antioch are not noted in the historical record, specifically because he was no longer a part of the quest to secure Jerusalem. Fulcher continues his chronicle as if he were with the main host, although he was not, because it was the completion of the armed pilgrimage to Jerusalem that was foremost in his mind. ${ }^{51}$ At one point Baldwin had enough success in consolidating his forces to march out of Edessa to assist his brother Godfrey in an assault on Azaz, where they defeated Ridwan of Aleppo, ${ }^{52}$ but it was not until after the fall of Jerusalem that Baldwin first visited that holy city, the object of the First Crusade. This fact may have had bearing on the later relations between Baldwin as king of Jerusalem and the Islamic cities that he had to negotiate with, such as Damascus. Baldwin was not a direct party to the bloodshed involved in the sack of Jerusalem. He would later enter and become king without personal connection to the conquest, but through inheritance as the younger brother of the most 'pious' Godfrey.

The reign of Baldwin as king began with the unexpected death of his brother after just one year of rule, in 1100. As Fulcher of Chartres blithely writes, Baldwin grieved for his brother, but celebrated in effect his own good fortune. Whether or not Baldwin

\footnotetext{
50 AA, 265-267.

$51 \mathrm{FC}, 71$.

52 AA, 345-355.
} 
realized at this juncture the immense task that was to await him as king, is a point which cannot be proved or answered. The enormous task of consolidating his hold on and preserving the kingdom was daunting to say the least. If the Christians who had left Europe wanted to remain in their newly won territories like the Israelites of the Old Testament upon entering the 'promised land,' they would need to conquer and consolidate it.

Thus when Fulcher of Chartres ends his second book with an epithet for King Baldwin I of Jerusalem, his likening him to a second Joshua is of fundamental interpretive importance. ${ }^{53}$ Like the first Joshua from the biblical book that bears his name, Baldwin took over not only the martial role of his brother Godfrey who had brought the 'chosen people' to their new home like a second Moses, but Baldwin also had to take in hand the spiritual and administrative roles if he was to keep factional infighting from breaking up the new Latin Kingdom. The parallels between the biblical narrative and the accomplishments of the crusaders who remained were well apparent to writers like Fulcher, who identified the ancient split kingdoms of Israel and Judah with the northern principality of Antioch and the southern one of Jerusalem. These parallels between the biblical world and the contemporary activities of the crusaders were important in understanding the events that occurred after the fall of Jerusalem, and in effect answered the 'what now?' question that emerged. The crusaders had won a strategically difficult place to defend when they took Jerusalem, but a spiritually important center for the new kingdom. Strong urban bases needed to be established, and

\footnotetext{
53 M.C. Gaposchkin, "Louis IX, crusade and the promise of Joshua in the Holy Land," Journal of Medieval History 34 (2008): 245-274. Gaposchkin argues that Joshua in the medieval context, was portrayed as not only a military leader, but as a king of the Israelites, which made a perfect comparison for clerical authors who wanted to laud the actions of Christian kings. FC, 222-223.
} 
the Christian garrisons strengthened, or the cities they had conquered would revert to the control of the Muslim communities they had fought so long to evict. ${ }^{54}$

For Fulcher in particular, the answer seemed obvious. Their responsibility was to occupy and reclaim all of the biblical lands, and so the literary memory of Baldwin as the first king required tying him to the idea of a second invasion of the 'chosen people' into Palestine. For the people of Europe who were being tempted to make the journey, the histories that Fulcher and Albert were writing were meant to not only record the events of the pilgrimage, but to encourage their audiences to see that God was achieving a second reclamation of His lands through His people under Baldwin and the lords of the northern kingdoms. Baldwin's actions support this claim, namely that of being a second Joshua, and account for the success and growth of the Latin Kingdom under his nearly twenty years of rule.

\footnotetext{
54 Mayer, Crusades, 43-50.
} 


\section{Chapter 2 - The Warrior King}

For contemporaries both within the holy land and outside of it, Baldwin's greatest contributions to the Latin Kingdom lay in his military activities. His immediate policy of action after taking the kingdom under control brought about a period of ever expanding conquests that lasted for most of his rule. The general success of this policy was measured by the addition of the important coastal cities of Arsuf, Acre, Caesarea, Beirut and Sidon which occupied important harbor sites from the south near Gaza to the northern border of the County of Tripoli. Only Ascalon which fell in 1153 and Tyre in 1124, escaped his grasp. In addition, the expeditions that led Baldwin through the east to the Red Sea, up to the contested border territories of Damascus, and eventually down towards Cairo, worked to create a large area of territory respected as now belonging to the Latins, and deterred the surrounding Islamic factions from invading with a large force. Baldwin's presence was felt everywhere. His ability to move quickly to the scene of a crisis rivaled similar behavior of western European monarchs, and challenged his opposition to think carefully before testing his defenses.

While the military endeavors of Baldwin are only one aspect of his governance of the infant kingdom, this chapter will attempt to outline his policies and actions as modern scholarship and contemporary accounts have understood them. Touching on the elements of his strategy, I will argue that Baldwin's choice of offensive versus defensive measures during the early years of the Latin Kingdom's rule, lasted through the next few generations to maintain the momentum with which he so vigorously began. This was 
primarily from necessity. The First Crusade had exposed a lack of coordination among the Islamic leaders. By testing the resolve of his enemies, and capitalizing on the weaknesses of the coastal cities, Baldwin achieved stability and expansion at great cost to his enemies.

While a look at the contemporary accounts will be vital to placing Baldwin's activities in the perspective of what actually occurred during his military campaigns, the final chapter will take an in-depth look at the interpretation of these years of Baldwin's military activities by Fulcher of Chartres. A generally rosier picture emerges from the chaplain's account, but one in which the facts can still be extrapolated and useful in completing the king's portrait as an effective and generally feared leader in the field.

\section{Man of Necessary Steel}

Baldwin of Edessa, as he was known upon his invitation to come to Jerusalem, learned an important lesson right from the beginning of his lengthy reign. With minimal troops, some 200 knights and 300 foot soldiers according to Fulcher of Chartres, Baldwin encountered an ambush that nearly wiped out his small army on the coastal road just north of Beirut, an encounter referred to as the Battle of Dog River. ${ }^{55}$ In a narrow corridor along the sea with high cliffs to his left, Baldwin found himself threatened from the heights above as well as by enemies aboard boats that had pulled to shore for the battle. As Fulcher of Chartres illustrates well, that day was a difficult one, and defeat had been a possibility, causing him and others to wish they were back in Chartres or Orléans. ${ }^{56}$ After holding off the enemy through the night, attempting to retreat in the

55 FC, 138-142.

56 FC, 139. 
morning, and then more desperate fighting, the victory went to the crusaders. Baldwin was allowed to continue on his way without harassment, receiving gestures of friendship and protection payments in the form of food from Beirut, Tyre, Sidon, and Acre.

The Battle of Dog River was pivotal to Baldwin's future interactions with his enemies in the holy land. This event north of Beirut marked the first time that Baldwin was opposed by a force he had not bothered to send scouts to look for. Unlike the progress of the First Crusade, he was not accompanied by his brothers or supported by another crusader lord. Unlike the invitation to occupy Edessa and to attack enemies of that city, he was in this situation effectively without a base of operations and forced to respond to the moves of the Fatimid Egyptians, which means they dictated his tactics on the occasion, choosing the time and place for battle. This element of being alone and not having the luxury of calling on others may have had an important effect on his future plans.

Fulcher of Chartres makes it clear that the victory at Dog River was achieved through quick and decisive moves on the part of Baldwin, consisting primarily of military probing and following up when he detected weaknesses. Baldwin was an effective leader of armies, particularly small ones, which is about all he ever had to work with in the newly conquered territories. The Battle of Dog River, if anything, taught Baldwin the importance of determining which side would do the reacting when first challenged to battle, and it was a lesson he put into practice. He also learned on this occasion, that the discipline of the enemy was not of the same quality as that of his own men, a decisive factor that could lead to the breaking of enemy lines in a pinch by acts of bravado or 
perceived suicidal charges. These two points were not new to many of the crusader lords that had been present at the battles for Antioch and Jerusalem, but Baldwin had not been at either of these sieges. Except for the attack on Nicaea and the journey with the combined armies until his reconnaissance towards Cilicia and the Syrian east, Baldwin had not encountered strong field armies, only defensive forces in cities and fortresses.

Whether or not Baldwin understood the condition of Jerusalem at the time of his acceptance of the crown, specifically that it was quite undermanned and under the thumb of its Latin patriarch, he comes across from the sources as determined to succeed in his new position as king. Within six days of arriving safely in the city and being greeted by its clergy and people, including Greeks and Syrian Christians according to Fulcher of Chartres, he set out on a campaign of shock and awe in and around his new domain. ${ }^{57}$ This swift and decisive reconnaissance would later support Fulcher of Chartres' assertion about Baldwin's role as a second Joshua. However at the time, the reality was that he needed money, for the kingdom treasury was depleted.

This raiding tour, for that is what it amounted to in material terms, with no lasting conquests to speak of, was an implementation of the lesson he had learned about calling the shots with the enemy by dictating the situation. His force of arms was not greatly augmented, even if he nearly doubled the men under his command. According to Albert of Aachen, Baldwin set out on his expedition with only 150 knights, and some 50 infantry; less than the total that he could have assembled. ${ }^{58}$ Fulcher of Chartres gives the complete number of men available for the defense of Jerusalem, Joppa, Ramla, and Haifa, as 300 knights and a few foot soldiers which, given the size of the cities and 
territory, seemed completely inadequate to contemporaries for protecting the walls of the kingdom's cities. ${ }^{59}$

This realization of being critically outnumbered must have been painfully obvious to Baldwin, if it had not already been clear before he set out to the City of David.

Many of the crusaders had gone home with their pilgrimage completed, and those that had remained were doubtless consigned to stay because they had gained property and some small degree of wealth that they felt compelled to protect and defend. ${ }^{60}$ In effect, Baldwin had taken over from his brother Godfrey a military camp, which was in a nonstrategic position from the start. Baldwin's actions, namely taking his forces into enemy territory to make his presence felt, was doubtless a defensive bluff that he hoped to augment with real force at some point in the future. This kind of aggressive action on his part sent out the message that there was still a considerable amount of fight left in the remnant of the western forces. Arguably, Baldwin's raids may have been designed to give any Latin rival pause, unsure of his intentions towards them.

The second most obvious reason for Baldwin's show of bravado, was the quest for money. His inheritance of the kingdom had not come with the wealth to support or feed his troops for long. The reputation gained from his work in Edessa and the victory at Dog River, according to Steven Runciman, preceded him, and it was a form of fame that he intended to exploit. ${ }^{61}$ The fall of Jerusalem had been marked not just by the killing of the inhabitants in July of 1099, but more importantly from an economical standpoint, the loss of a taxable citizenry. The ways in which Baldwin addressed this unfortunate

$59 \mathrm{FC}, 150$.

60 Housley, Cross, 6-7.

61 Steven Runciman, A History of the Crusades: The Kingdom of Jerusalem and the Frankish East 1100-1187, vol. 2 (Cambridge: Cambridge University Press, 1954), 71-72. 
decision on the part of the crusaders will be discussed later, but at the time it is arguable that the conquerors had expected a more or less immediate return of the Lord, making the maintenance of a subjugated populace not altogether necessary in their minds.

Baldwin's first energetic actions, then, stemmed more from a desire to survive. It is safe to say that Fulcher of Chartres, who as chaplain observed and even attended the king in some of these battles, did not consider it worthwhile to focus on the kingdom's precarious state of affairs in his history. The deeds of the Franks that he records are laudatory, praising a generally victorious European invasion of Palestine, and it is easy to see how his interpretation of Baldwin's role as continuing the work of a divine plan fit the scenario he saw unfolding. The conquests were expected to be easy by those that saw God's hand in the work before them, and Baldwin's actions fit the understanding of both the ecclesiastical community as well as the lay.

No Christian kingdom of Europe held legitimate claim to the new principalities of the crusader states, as Joshua Prawer pointed out in his influential study. ${ }^{62}$ Baldwin laid claim to territory that was held together by coercion and force, with little other real justification aside from an ideological premise. The First Crusade involved a coalition of armies that were never again to reach the same numerical size in later crusades, leaving the kingdom in a perilous state upon their departure. Jerusalem's population had been decimated. The kingdom need a source of income and there were few other options available to Baldwin if he did not want to risk the loss of his new patrimony. He was forced to grab the bull by the horns and to engage in kingdom-making at the edge of a sword.

62 Prawer, Kingdom, 471-473. 
Credit for Baldwin's victories must be reserved to his leadership skills and his recognition of what the situation required. After his reconnaissance of the southern territory in 1100, he returned to Jerusalem to accept the crown from Patriarch Daimbert in Bethlehem, swearing an oath of protection regarding the sanctity of the Holy Sepulcher, and nothing more. He had achieved his goal of consolidating support within the kingdom around his election, having given the lay magnates a demonstration of his ability to lead. ${ }^{63}$

The capture and exile of Bohemond of Antioch in 1100 resulted in the temporary departure of Tancred his nephew from the region of Galilee, which in effect gave Baldwin a wide frontier region to the north. ${ }^{64}$ This left Baldwin free to organize his response to the local threats without a rival nearby trying to make his own crusader state, and was a fortunate coincidence for Baldwin and his control over the Latin kingdom. At this point, Baldwin appears to have grasped what needed to be done if the various factions vying for control of the east were to be kept in check. Consolidation and followup on the recent victories of the crusaders was called for. Despite his limited resources in men and arms, he had to strike quickly and decisively, catching his opponents off guard as he had done at the battle north of Beirut. It was a lesson that had been reinforced by his opponents, and Baldwin rarely seems to have forgotten things he learned by past experiences.

\section{Driven to the Sea}

As stated before, Baldwin's greatest problem on his accession to the crown of ${ }^{63}$ Prawer, Kingdom, 474.

${ }^{64}$ AA, 523-525. 
Jerusalem was his limited manpower. The issue was two-fold. On the one hand there was a slow stream of pilgrims coming to the holy land, but not all stayed or planned to contribute militarily. Some came as armed soldiers prepared to fight if need be, but at the same time these men were usually few in number and self appointed guardians of noncombatants making their pilgrimage, usually leaving when their companions did. ${ }^{65}$ Almost immediately after the success of 1099, another group of crusaders left the west in 1101, many former deserters under the leadership of Stephen of Blois, and would have constituted a great addition of manpower had they not been virtually destroyed on the route to Damascus. ${ }^{66}$ The transient nature of pilgrimage meant that many of these pilgrims needed adequate reason to stay in the kingdom, since most had come to fulfill a penitential oath by bathing in the Jordan river or visiting the holy places of Jerusalem. ${ }^{67}$

Houses in the holy city itself were to be had for the taking, as the former population had either been killed or expelled, leaving three-quarters of Jerusalem empty. There was thus room for growth if people from the west were seeking a new home and change in their fortunes. Former serfs were not required to remain in the west with their lords, if they took the cross and went to the east. Freeman status had been guaranteed by the pope, and there was no legal reason why a family could not up and transplant itself to a comparatively palatial residence in the east. However, even if settlers did come, this did not necessarily guarantee an increase in manpower for the Latin Kingdom and its army in the field. Some measure of security in the form of local militias prepared to

\footnotetext{
65 Tyerman, God's War, 178-179.

66 Housley, Cross, 106-107. 88-94.

67 R.C. Smail, Crusading Warefare 1097-1193 (Cambridge: Cambridge University Press, 1995),
} 
defend cities and castles could be attributed to these settlers, but little else. ${ }^{68}$

The second problem for Baldwin was a lack of money. He had little in reserve after leaving the County of Edessa to his cousin Baldwin of Bourcq, and as stated before, found the kingdom's coffers virtually empty upon his arrival. Those in his army with experience in war demanded payment for their services. Mercenaries were easily hired and somewhat experienced fighters, but they too demanded adequate payment to remain loyal and on the battlefield. Where Baldwin would get this money was a nagging problem of his entire rule, and was never so problematic as at the beginning. Raiding was a lucrative form of raising cash or goods that worked as the equivalent for payment to his soldiers, until caravan routes began to change in response. ${ }^{69}$

As scholars have repeatedly noted, the early years of the kings of Jerusalem were marked by the retention of royal lands, and the issuing of the fiefs de besant, the so-called money fiefs, a form of cash entitlement for the knights that fought in the armies of the kings. Prawer attributes this tactic to a desire by specifically both Godfrey and Baldwin I to keep royal power unchallenged by a landed nobility, as well as streamlining the effective command of the army under a single leader who guaranteed payment. The kingdom that Baldwin had inherited had potential because it was large enough territorially to make sure that his forces were paid, but only if he had the people to work the land and to gather the taxes forced upon the conquered residents in the countryside. In addition, trade opportunities with the Italian city states had not yet had a significant impact on the kingdom's economy. ${ }^{70}$

\footnotetext{
68 Prawer, Kingdom, 38-40.

69 Runciman, A History, 72.

70 Prawer, Kingdom, 126-128.
} 
These two problems of manpower and money could be addressed at the same time by the acquisition of new coastal territories, specifically those that allowed access from the west of fresh recruits and promised commercial incentives to the Italian city states. This idea was not altogether new, nor was it lost on the crusaders that one of the main causes of their success during the march to Jerusalem was the naval support they received from the Byzantines, and in particular from the island of Cyprus. Although contemporary writers did much to downplay the importance of this element, the fact remained that without the timely help that the crusaders received from the sea from the Byzantines, Italians, English pirates, and Scandinavians, the conquest of Jerusalem would not have been possible in the first place..$^{71}$

Baldwin I was not a stranger to either military strategy or supply logistics from what the contemporary records show. He realized that the holy city was linked by a slim lifeline corridor that passed through Ramleh, on towards the coast and Jaffa. The latter was not a particularly large port, and was not blessed with a harbor that was congenial to heavy traffic in pilgrims or commerce. The natural choice for the king was to establish a solid base for incoming troops, allies, and revenues generated from trade. So he embarked on a mission to subdue the coastline, beginning with Arsuf in 1101.

The capture of the city was made possible not by the forces at hand, but by a coalition between the kingdom's forces and those of Genoa. The timely arrival of the papal legate Maurice, Cardinal-Bishop of Porto, had unexpected benefits. As Runciman argues, the Genoese had not yet been greatly involved in the holy land, and appeared to be following the example of the Pisans in sending a fleet to see what might be

\footnotetext{
71 John France, Victory in the East: A Military History of the First Crusade (Cambridge: Cambridge University Press, 1994), 208-211.
} 
accomplished if the opportunity presented itself. The Pisan fleet escorting Daimbert in 1100 had played a crucial role when it came to installing him in the senior church position in the kingdom as patriarch of Jerusalem. At this juncture in his career, Baldwin took the opportunity to strike a military and commercial agreement with the Genoese. ${ }^{72}$

Promising the Italians a third of the city, their own street, and various trade privileges, the king secured the aid of fellow Christians. Prawer recognized the fact that this early stage of negotiation between the kingdom's rulers and the Italian states was far more beneficial to the Genoese than the Latin Kingdom, creating as it did a special separate community with its own rights within the settlements on the coast. ${ }^{73}$ Such an accord was most certainly related to the reality of the kingdom's needs on the ground, namely that besieging a coastal city with access to the sea and potentially supported by its own naval forces supplying food, would be nearly impossible without some kind of fleet. A deal had to be made, or preparations for a long and possibly dangerous siege around the cities would be the only alternative. Baldwin solicited the alliance of the Genoese, a mercantile power that would bring him aid and, more importantly, secure a port for incoming pilgrims and commerce. The result was the capitulation of Arsuf in early March under an agreement that Baldwin would honor the families that surrendered and allow them access to Muslim-ruled lands. ${ }^{74}$

The capture of Caesarea followed not long after, and it was accompanied by a sack of the city by the soldiers. Runciman argues that Baldwin was making a point by sacking the city, demonstrating his fairness towards those that acknowledged his

\footnotetext{
72 Runciman, A History, 72-73.

73 Prawer, Kingdom, 489-492.

74 FC, 151-153.
} 
superiority and surrendered, and his ruthless attitude towards those that resisted. ${ }^{75}$ What Runciman failed to account for in his understanding of the situation, was the fact that the city defenders obliged Baldwin to fight for the prize, and it was not an unexpected reality in the state of warfare, that soldiers were rewarded with spoils from captured cities as part of their service rights. ${ }^{76}$ Baldwin had been present at the siege of Nicaea in 1097, and would have well remembered the resentment the western armies had felt when they found that the city had been given over to the Byzantines by the enemy garrison to avoid a sack.

Baldwin may have had the ability to stop the pillaging and to protect Caesarea's inhabitants, but at what cost to his authority? Humane treatment of the defeated would be laudable to a modern audience, but hardly reflect on this period as the king was defending and aggrandizing his kingdom, founded on a policy of wresting it away from the local populations. It may have been with some relief that he found his soldiers acquiring wealth, which would only strengthen their support of his leadership. It was becoming clear that his rule would be lucrative for his followers. On the other hand, extending to his opponents the opportunity to walk away unscathed after fighting for the city, might have appeared to be an attempt to secure the city's wealth for himself, at a cost to his men who had worked hard to bring it about. Baldwin had to demonstrate strength and severity towards his enemies when they resisted, or his prestige and the confidence of his men would have been diminished.

This period of Baldwin's rule also witnessed a series of tests in his leadership of the royal army. The First Battle of Ramleh occurred late in 1101, and involved a large force of Egyptians sent by way of Ascalon. Baldwin's forces were divided into five

\footnotetext{
75 Runciman, A History, 73-74.
}

76 Tyerman, God's Wars, 22-24. 
groups, two of which were led by him directly, and the battle was a close call from what can be determined by Fulcher of Chartres, who witnessed it while accompanying the True Cross carried by the patriarch, and later by Albert of Aachen, who reported what he had been told by men who returned after the event. This is the only occasion upon which Baldwin is actually recorded to have made a stirring speech during the very heat of the battle, having first confessed and been absolved of his sins in case he should die on the field.

Come then, soldiers of Christ, be of good cheer and fear nothing! Conduct yourselves manfully and ye shall be mighty in this battle. Fight, I beseech you, for the salvation of your souls; exalt everywhere the name of Christ whom these degenerate ones always vigorously revile and reproach, believing in neither his Nativity nor Resurrection. If you should be slain here, you will surely be among the blessed. Already the gate of the Kingdom of Heaven is open to you. If you survive as victors you will shine in glory among all Christians. If, however, you wish to flee remember that France is indeed a long distance away. ${ }^{77}$

Baldwin's speech was short and to the point. Particularly interesting is the somewhat humorous dismissal at the end which degraded the role of the defector or coward, both types that claim a special derision from Fulcher of Chartres. ${ }^{78}$ Baldwin's speech exemplifies an ideology that fueled the momentum of the crusaders who stayed

77 FC, 157-158; RHC Oc. Vol.4, 392, "Eia Christi milites, confortamini, nihil metuentes. Viriliter agite, et in hoc praelio fortes estote, et pro animabus vestris, quaeso, pugnate, et nomen Christi omnino exaltate, cui degeneres isti semper exprobrant, et viriliter convicaiantur, nativitatem ejus non credentes neque reurrectionem. Quod si hic interieritis, beati nimirum eritis. Jamjamque aperta est vobis janua regnia coelestis. Si vivi victores remanseritis, inter omnes Christanos gloriosi fulgebutus; si autem fugere volueritis, Francia equidem longe est a vobis." Of particularly interesting note in this exaltation, is the association of the nearness of the both the birth place of Christ and the place of his Resurrection. As if the soldiers had cause to doubt the reason for their fight, Baldwin commands attention by summarizing in just a few lines the reason for the battle. The war is against the unbelievers, the ridiculers of Christ who are already judged. There is an indisputable place for those who perish in this holy endeavor, namely the Kingdom of Heaven. Finally they should not fear, just as the angels had spoken to the shepherds announcing the birth of Christ, and even if they wished too, the lands they had left behind, like their old lives, were far away.

78 FC, 97, 169. The poverty of the Christian army outside of Antioch and the flight of the men who were supposed to be leading the crusade, such as the renowned Stephen, Count of Blois, deeply disturbed Fulcher. 
and fought for their place in the holy land. Christ's soldiers had captured the city, and it was their honor to maintain it for Him. While doing so, it is obvious that Baldwin in this speech believes that the act of martyrdom is still a guaranteed way to salvation, suggesting that the concept of the indulgence and remission of sins for the crusaders would last as long as they continued to fight the Muslim enemy.

Of the few occasions on which Fulcher reports Baldwin actually speaking, this is the longest and does bear some reason for scrutiny. Although it is perfectly possible that he did indeed give this speech and that contemporaries would recall that the written form was fairly true to the moment, there is a question as to whether or not Fulcher wished this to be the essence of what the king had said. Baldwin's education in the church would have given him the necessary theological background, and the fact that his men followed his orders consistently, suggest that he could speak with persuasion and clarity when the occasion demanded it. More importantly, this battle against a large Egyptian force helped Fulcher to extoll the virtues of his hero, hindsight from his second redaction in 1124 possibly coloring his memory of the event. The victory was vitally important to the defense and peace of the kingdom, and only added to Baldwin's reputation as being a champion against the foe and therefore legitimated by God in the eyes of his subjects.

Yet the peace following 1101 was not to last long. The royal army was defeated in mid-May of 1102 at the Second Battle of Ramleh, and the desperate escape of the king after the battle revealed that Baldwin had underestimated his opponents. Baldwin had received word that the forces of the Egyptians were far less threatening than he should have been prepared for. The truth was a little late in coming to him, and with a force of 
about 500 knights, including pilgrims from the failed crusade of 1101 who had survived the devastation of their movement in northern Syria, Baldwin risked an all or nothing battle. That the king escaped the debacle, is recorded in the narrative as a daring adventure which was allowed by the mercy of God to succeed, according to Fulcher of Chartres. The eventual victory of the king over his enemies with the timely help of a fleet of English and German pilgrims arriving in the port of Jaffa to help the king defeat the Egyptians, was seen by contemporaries as the crowning revelation of God's favor after a short time of discipline for their sins. ${ }^{79}$

Following the defeat in Ramleh, the kingdom's fate rested for a few days on the uncertainty of the monarch's whereabouts. Had Baldwin perished in this battle or its aftermath, the chance that Tancred would have come back to the southern kingdom to assert himself was high. However, in spite of Baldwin's seemingly good luck in getting the right help at key moments during his flight from the enemy, and eventually obtaining the support he needed to defeat the battalions outside of Jaffa, ${ }^{80}$ credit for organizing the reply to the Egyptian forces must lie with him. Baldwin I never found himself again in the same situation of running for his life. There was another battle which he lost in 1113 against the Fatimid army, owing primarily to his audacity in taking the fight to the enemy before his allies had arrived, yet he did not flee but took up a defensive position and rallied his troops. ${ }^{81}$ Though the end result was a stalemate in which the enemy eventually reached the rural area around Jerusalem, the invasion came to nothing of consequence because Baldwin did not engage again with the enemy, which would have risked the

79 FC, 169-174.

80 Runciman, A History, 80.

81 FC, 205-208. The king had requested the aid of Roger, the Regent of Antioch, and Pons, Count of Tripoli, but foolishly did not wait for it to arrive. 
royal army. A generally cautious individual despite his warlike reputation, he learned to regard the enemy with respect, and the kingdom was the better for it.

The battles for Acre (1104), Beirut (1109), and Sidon (1110) were equally challenging for the king, and it is important to note that these took place a few years after his first success along the southern part of the coast. The Christian observance of Easter occasioned large pilgrimages to Jerusalem, and thus was an opportune time for the king to solicit the assistance of potential allies in his goal to extend the royal domain. ${ }^{82}$ Acre, the largest and economically most important port of the Latin Kingdom, was taken in 1104 with the help of the Genoese and the Pisans. Baldwin had failed to take Acre the year before, and during the celebration of Easter, he approached the Genoese and Pisans about a joint venture with their fleets against this city. The end result was the capitulation of Acre to the king with the understanding that the citizens who wished to leave could depart with their families and goods, while those that remained behind could assure themselves of favorable treatment by a monetary payment to the king. ${ }^{83}$ This is the account as it is presented by William of Tyre, and Fulcher of Chartres says little in his narrative, except that the city was taken, that some people were killed, and that few were spared. ${ }^{84}$ Fulcher is strangely vague in this account and may have been ignorant of what had happened, but it is more probable that he merely did not want to expound further on a scenario that did not present Baldwin in the best light as king.

It is Albert of Aachen who explains at length what occurred after the siege, pointedly accusing the Genoese and Pisans of incredible greed and reluctance to allow

\footnotetext{
82 Housley, Cross, 82-83.

83 WT, 454-456.

84 FC, 176.
} 
the citizens to surrender and walk away with their valuables. Somehow Baldwin and the Patriarch Evremar convinced their Italian allies to submit to the king's lenient terms with the citizens, but in the end the Genoese and the Pisans could not handle seeing the wealth being borne out of the city and away from them, and finally broke the truce and attacked. Albert of Aachen describes the final scene of this sad account with the king in a great rage, wishing to punish the Italians severely for betraying his honor in this matter. Only the supplications of the patriarch Evermar and the clergy were able to change Baldwin's mind. ${ }^{85}$

Although Baldwin was recognized by his contemporaries for being cunning and heavy-handed, all the talent at his disposal could not make up in every case for the absence of men. While Albert of Aachen's description of the events of the siege of Acre were different and somewhat more realistic than the other two chroniclers', the truth is more than likely somewhere in the middle. William of Tyre and Fulcher of Chartres were both of royalist bent, and carefully avoided putting the king himself in the wrong. Albert likewise vilifies the Italians in a way that only brings Baldwin into a better light. He excuses the issue of betraying the residents of Acre by showing the king's ultimately powerless position to oppose his allies and their single-minded greed. It is also possible that Baldwin had an agreement with some of the citizens of the city and protected them, but was not able to do so in all cases, thus the reason for painting a darker picture of his allies who did not have to give him complete obedience, since they were actually partners in a joint enterprise. Given the general absence of commentary upon the siege of Acre in 1104 by modern scholars, it is clear that many historians consider Baldwin to have

\footnotetext{
85 AA, 671-675.
} 
presided indifferently over another general slaughter.

Yet it is apparent that Baldwin was often just a senior member of joint ventures. This last argument seems to be born out particularly by Fulcher of Chartres in his account of the capture of Tripoli, a joint venture a few years later in 1109 between Baldwin and the heirs of Count Raymond IV of Toulouse. During this episode, the dispute between Bertrand and William Jordan as to whom should inherit the old count's conquests in the holy land came to an end with the timely death of William. The final capture of Tripoli with the help of the Genoese witnessed the citizens once again despoiled and killed by the predation of the king's Italian allies. Uniquely, Fulcher of Chartres says specifically that those in the vicinity of the king were spared according to the agreement he had made with them. ${ }^{86}$ This suggests a much earlier parallel in which Count Raymond himself had secured the safety of certain rich Islamic citizens in the Tower of David during the sack of Jerusalem in 1099 , but only those that agreed to monetary terms ${ }^{87}$ Doubtless Fulcher would not have wanted to suggest an equally money-driven motivation between Baldwin and Count Raymond's actions, however the comparison is illuminating in supporting the notion that the king of Jerusalem had power and a certain degree of command, but only within defined terms. He was a powerful player in the holy land campaigns, but by no means the most important. Baldwin was still heavily reliant upon recognition of his leadership and authority by his allies; including the ability to make deals regarding the destiny of the spoils and leniency towards conquered populations.

The capture of Beirut in 1109 with the assistance of Bertrand, now count of Tripoli, and the Genoese and Pisans, was not particularly exceptional in the ongoing 
conquest of cities by the crusaders. Fulcher of Chartres characterizes the siege almost solely by the amount of time involved, a seventy-five day ordeal in which the victors finally secured the city and took all the money of those trying to escape. ${ }^{88}$ Albert of Aachen claims that the relatively poor city was mercilessly put to slaughter by Bertrand and the Pisans, during which 20,000 souls were slain while the gold and silver that the crusaders sought had been secretly shipped out to Cyprus along with the former amir of the city. ${ }^{89}$ While obviously an exaggeration in figures, the killing must have been substantial. William of Tyre's only addition to this scene of violence, is the fact that Baldwin is supposed to have decried the butchery and ordered a halt to it and clemency to those that sought his mercy. ${ }^{90}$ The possibility that this was indeed the case is predicated on two reasons, namely that Bertrand owed his position in the County of Tripoli to the king, as will be seen in the next chapter, and that no account of Baldwin's acts, excluding the sack of Caesarea, demonstrate him as overtly willing to put the populations of conquests to the slaughter. Baldwin thus had the authority to stop the killing, and could only benefit from its halt.

While Albert of Aachen's rather unrealistic accounting of those killed strains belief, his narrative is once again suggestive of competing goals. On the one hand there are the two groups that wanted to make an easy profit through sack and pillage, Bertrand and the Italians. On the other side is Baldwin, who has a plan for the eventual incorporation of the city and its surviving residents into the economy of the Kingdom of Jerusalem. Though not regarded as a humanitarian, the king does come across repeatedly

\footnotetext{
88 FC, 196-197.

89 AA, 787-793.

90 WT, 484-486.
} 
as being far more interested in preserving the native populations, if only to keep them as his own taxable subjects. ${ }^{91}$ This stands in contrast to the assumption that the crusaders only killed for religious or monetary gratification alone. Baldwin was more than willing to take a bribe or a hefty payment for privileges, yet he was ultimately concerned to protect those that came to him for safety in an effort to forward the well-being of the kingdom. Baldwin appears through his action to be a realist who was practical and not driven to waste what was already at hand.

The siege of Sidon in 1110 and the parties involved in its capture are unique in the history of the post-war years of the First Crusade, for three reasons. For the first time a foreign monarch arrived in the holy land as a crusader, in the person of Sigurd Magnusson, joint ruler with his brother over Norway. Setting out in 1107 and taking a roundabout journey by sea that passed England and Spain, and then traveling through the Mediterranean, Sigurd and his followers arrived in the holy land in the fall of $1110 .{ }^{92}$ The next time a king of the west would come after Sigurd I, would be during the crisis set off by the capture of Edessa in 1144, which launched the Second Crusade led by Louis VII of France and Conrad III of Germany. ${ }^{93}$

Sigurd had the somewhat convenient luxury of being the younger co-ruler of Norway. Thus he had the freedom to engage in an adventurous journey that eventually ended with an overland return trip through Constantinople where he left his ships with the emperor, and the eventual welcome home and a new title of "the Crusader" to add to his 91 Tyerman, God's War, 205-206.

92 AA, 799-801.

93 WT, 163-164, Jonathan Phillips; The Second Crusade: Extending the Frontiers of Christendom (New Haven: Yale University Press, 2007). Phillips' work looks quite closely at the players involved in launching the crusade, such as St. Bernard of Clairvaux and Pope Eugenius III, and the eventual disaster of the French and German armies, which destroyed a generally neutral relationship between the Latin Kingdom and Damascus. 
list of honors. Few other western rulers had the time, the security, or the resources available for such a trip. ${ }^{94}$

Secondly, the siege of Sidon became in a short space of time the center of a hotly disputed war between parties that all had specific purposes in mind for being there. The Norwegians had come for the value of penitent pilgrimage and to be involved in the holy war. The king of Jerusalem saw an opportunity to advance his cause and prestige by welcoming the assistance of his foreign equal, another king who recognized Baldwin's legitimate rule, and a chance to add to the kingdom's size. The Venetians saw an opportunity to advance their cause over the other Italian merchant states by assisting and gaining access to an eastern Mediterranean port, and were led by the Doge himself, Ordelafo Falieri. ${ }^{95}$ In opposition to these allies, the Egyptian fleet had arrived to back up its claim that the Fatimid leadership was still an effective player in the war against the westerners and not just interested in the city of Ascalon as a launching point for invasion. It can also be said that belatedly, the Egyptian leadership realized that one of the last effective ports for their interests in staying connected with Damascus was threatened, and were finally roused to launch the fleet.

All of the above reasons are highlighted by the final point that Sidon was not an important port, and never did reach the status of anything like Acre with its reinforced military walls and central place in the commercial vibrancy of the kingdom. ${ }^{96}$ Sidon was, if anything, a success more by the fact that it was eventually captured and could reflect positively on the crusader alliances and partnership with other mercantile-minded

94 Snorri Sturluson, "Heimskringla," in Early Travels in Palestine (New York: KTAV Publishing, 1968), 50-62.

95 Runciman, A History, 92-93.

96 Prawer, Kingdom, 87-88. 
Christians from the west, than it was a territorial acquisition. Equally, the coalition which defeated the far wealthier and militarily stronger Egyptian forces, the Islamic opposition on the defensive and stopped any further serious attacks for the immediate future. Assistance from the west was unpredictable except that it usually came in the spring time, and the investment of manpower both temporary and permanent in the east was something that could not be known in advance by the men of Damascus or Cairo. It can be conjectured that there was fear that such an offensive would result in another crusade on the scale of the first one. However, the disaster of the Second Crusade demonstrated that even under the guidance of two kings, the power of the west was not as great as might be supposed and could be defeated if its armies were divided. ${ }^{97}$

Contemporary writers were not particularly amazed at the outcome of the siege of Sidon, for it was assumed to be a forgone conclusion that the warriors of God would ultimately triumph in the end. However, Fulcher of Chartres details Baldwin's reception of the Norwegian dignitaries, escorting them around the holy places personally, and involving them specifically in his plans to attack the city. Fulcher does a disservice to Sigurd in his account, not only forgetting to mention the king's name, only suggesting a royal position by assigning the foreigner kinship with the ruler of Norway. ${ }^{98}$ William of Tyre does a little better by mentioning that Sigurd was the brother of the king, and thus at least royalty. ${ }^{99}$ Arguably, Fulcher's omission of Sigurd's name and his tendency to downplay Sigurd's royal position, is an attempt to show Baldwin in a slightly elevated position over his distinguished guest.

\footnotetext{
97 Phillips, 269-279.

98 FC, 201-202.

99 WT, 486-488.
} 
The siege proceeded according to plan, until the Egyptian flotilla arrived and caused concern by threatening the Norwegian position as it blocked the harbor. The timely arrival of the Venetians alarmed the enemy however, and rather than risk a battle, the Egyptians sailed away, leaving the coastal city to its fate. ${ }^{100}$ Sidon fared better than the other port cities mentioned so far, receiving good treatment on terms of surrender to Baldwin. It is possible that the presence of three powerful leaders with the authority to crack down on their troops had an impact, but on the other hand it is equally possible that Sidon did not possess the wealth to tempt a sack of the city by its conquerors.

Though Baldwin never did take Tyre and Ascalon, which alone of the coastal cities eluded him, the firm hold on the coast that he achieved was made possible by his own planning and daring and the ability to negotiate with other interested parties. During his reign the internal security of the kingdom was better than it would be under his successor, almost certainly by his well earned reputation as a fighter and his energetic response to intrusions on his realm. All of the contemporary accounts attribute these successes to his outrageous nerve and audacity in spite of the stronger powers surrounding the kingdom, and the bluff worked well in combination with strategy and skill. The proof lies in the positive outcome. When Baldwin had to fight, effective leadership and moral encouragement in the form of sermons and the presence of the True Cross, often saw the victory over numerically superior forces going to the king, as at the Third Battle of Ramleh in 1105. ${ }^{101}$ This was the last great invasion for nearly eight years, giving Baldwin a much freer hand for action in his realm.

The later expeditions of Baldwin bear note in his final years as king. His journeys 100 John Julias Norwich, The History of Venice (New York: Borzoi Books, 1982), 81-84. 101 FC, 182-185. 
east to the Red Sea and the building of Montreal on the road to Aqabah, were not just curiosity trips as suggested by Fulcher of Chartres, but in fact it was more than likely that Baldwin was testing the ability of the eastern desert barrier to resist an army. These sojourns were similar to the immediate raiding tour he took right after his assumption of the kingship, a move used to intimidate potential threats by unexpected actions and the appearance of being able to go anywhere at a moment's notice.

The first time that he entered Arabia, in Fulcher of Chartres' words, he called the castle he constructed Montreal, "in honor of himself because he built it in a short time with a few men and with great boldness." 102 This was in 1115, and for a reason unspecified by the chaplain, the king followed up by taking the second trip a year later to see what he could find at the Red Sea and what he might want. Having scared off the residents of a city called Elim, Baldwin left the east for home and perhaps to demonstrate the insignificance of the adventure, Fulcher of Chartres spends the next few chapters of his work focusing on the natural features of the Red Sea and its local lore. The end result that can be deduced was that there was nothing worth gaining out in the farther reaches of the east. ${ }^{103}$

The final journey of Baldwin towards Egypt seems to have been an attempt at gauging the actual resistance that the Fatimid forces would put up against his incursion into their territory. The raiding of caravans that he engaged in on the way, and the opportunity to stop and eat fish that his men had caught, suggest that there simply was no resistance to his movements. Whether or not he would have tested the walls of Cairo

\footnotetext{
102 FC, 215-216; RHC Oc. 431, "Quod castrum ob honorificentiam sui Regalem Montem nominari constituit, quia parvo tempore cum pauca gente, sed macima probitate, illud aedificaverat." 103 FC, 216-218.
} 
itself is uncertain, for the food poisoning that he incurred from the fish or the agitation of an old internal wound which may have caused infection, laid him low quickly. His rapid illness and death on the second day of April, brought to an end any serious thought of attacking Egypt directly for several decades. ${ }^{104}$ It is safe to guess, though, that Baldwin would have challenged the Egyptians in a moment if he detected weakness in their stance against him. Baldwin's defensive policy for the Latin Kingdom of Jerusalem was, in most cases, a good offense, in which he attempted to make the enemy react to his movements, not the reverse.

\section{Conclusion}

As demonstrated through an assessment of Baldwin's major military victories and defeats over his nearly twenty-year period of rule, the king was initially pushed to territorial aggrandizement by a need for secure support lines to the west. With a combination of offensive bluffing that cowed many of his opponents from consolidating their forces, Baldwin used his windows of opportunity wisely to extend his control up and down the coast with what available allies he could negotiate with, often on generous terms, demonstrating his relatively weak bargaining power. However, the kingdom at his death was on a much better footing than when he had received it from Godfrey, and the success of Baldwin II owed not a small debt to the actions of the restless king.

While contemporaries differed at times on the accounts of the military events of Baldwin's rule, and modern scholars have hinted at a ruthless nature in his actions regarding captured cities, from the point of view that the Latin Kingdom needed a strong

104 FC, 221-223. 
and versatile king, a better man could not be found among the surviving leaders of the First Crusade. Baldwin was a clever opportunist that often fought in the position of the audacious underdog, and yet his style and reputation made it seem that he was the most important leader involved. While it is not the place of the historian to guess at "what ifs," it is arguable that had he lived another ten years, Fatimid Egypt might have been overthrown by a new Latin overlord, and the nature of the history of the crusades would have been significantly altered. 


\section{Chapter 3 - The King and Church}

The external enemies of the Latin Kingdom came to respect Baldwin I for his military exploits, but the security of the realm was not founded just on the battlefield. Baldwin's domestic enemies learned from the start of his reign the skill with which he would exercise his new position through negotiation, mediation, and manipulation. All three abilities have been seen in the former chapter, and were just as important for the king of Jerusalem to use against divisive elements within the kingdom.

As I will argue, powerful members of the ecclesiastical hierarchy envisioned a theocratic state in the holy land after the successful conquest of Jerusalem. As they did in Europe, bishops in the holy land often acted the part of secular landed gentry and provided military backing for the protection of the lands within their sees. However, the crusader principalities needed strong, united leadership if they were to last, and central authority could not be as divided as it often was back in continental Europe. Later the military orders would shore up the power base from which the kings could draw support; they constituted an armed branch of the Church which was responsible for serving the best interests of the kingdom. However, that transformation would only begin under Baldwin II (1118-1131).

One of the first important changes to take place, was Baldwin I's achievement in doing away with the title of "Protector of the Sepulcher," which Godfrey had assumed. Though the chronicles expressly stress that Godfrey did not take the title of king, the nature of his authority and rule is somewhat obscured by the undefined title of $d u x$ or 
princeps. Baldwin clearly followed a policy of aggrandizing the royal power and influence of his position by taking a hand in determining what man would occupy the most powerful ecclesiastical position in the east: the patriarchate of Jerusalem. His deep involvement combined with the ascendancy of a politically weaker pope, Pascal II (10991118), enabled Baldwin to set a precedence for the right of the kings of the Latin Kingdom to have a significant say in the ecclesiastical leadership of Jerusalem, as well as the election of prelates to its offices.

The second aspect of Baldwin's rule to examine, is his relationship to local elites through arbitration and control, policies towards his own marriages and the regnal succession. I will argue that Baldwin purposely kept much of the royal domain in either his own hands or under the watch of men he fully trusted, maintaining a strong position from which to rule the kingdom so that his offensive and defensive military options were maintained without hindrance. His leadership impressed upon his contemporaries that he was the right man to arbitrate disputes, such as those between Bertrand and William Jordan in Tripoli in 1109, and Baldwin of Bourcq and Joscelin of Edessa in 1113. Baldwin's later problems regarding his marriages to Arda of Armenia and Adelaide of Sicily raised issues not only of the succession, but of what the king was trying to achieve for stability of the realm. I will argue that in this regard, Baldwin's marriages were always for money or politics, including his first marriage to Godehilde, and that the succession was more or less planned to pass to the only kinsman still in the holy land who had a knowledge of the enemy and local political issues, Baldwin of Bourcq.

The final aspect of Baldwin's rule to consider is his attempts to maintain a 
negotiated neutrality with Turkish-ruled Damascus in the east, which was maintained off and on by both parties; his attitude towards the other Christian sects found within the kingdom; and the stance he took towards repopulating Jerusalem in the final decade of his rule. My argument is that Baldwin pursued a policy to solidify his political and material gains, as well as to secure an income for the rising expense of an army that was needed to secure the kingdom's borders. These two aims required negotiation and mediation as previously suggested, and Baldwin was effective in achieving both aims and leaving his successor a throne that was stronger and more respected by friend and foe alike than when he had ascended it.

\section{The Church and the State}

The dispute over whose city Jerusalem really was began almost immediately after its conquest. In the spring of 1100 , while many of the crusaders were heading home from their recent conquest and finally completing their pilgrimage, a Pisan fleet brought the new papal legate, Archbishop Daimbert (1092-1099), to confirm the decisions that the ecclesiastical hierarchy of Jerusalem had made regarding the office of patriarch, a nomination that had gone to Arnulf of Chocques. John Rowe argues that the decision to elect Arnulf, a former chaplain of Robert Curthose, was widely supported by the lay crusade leaders. Arnulf never challenged Godfrey's position as Advocate of the Holy Sepulcher by attempting to assert control over the king, which suggests he knew that he had to work with the establishment if he were to succeed in his position. The prestige of the office of patriarch of Jerusalem was no little thing in the minds of medieval 
Europeans, and was the highest ecclesiastical authority in the east. ${ }^{105}$

Unfortunately for Arnulf, the arrival of the Pisan archbishop upset what might have been a fairly peaceful beginning to the Latin patriarchate of Jerusalem. Godfrey welcomed Daimbert as a representative of the pope; however, the archbishop questioned the legitimacy of Arnulf's election. The papal legate engineered a deposition, and followed up by convincing the assembly to allow himself to fill the position. Arnulf was accused of bribery and womanizing, both justifiably. Arnulf was disgraced and deposed, but was neither out of the picture nor willing to give up his designs on the lost office. He would prove to be a thorn in the side of nearly every subsequent patriarch. ${ }^{106}$

Daimbert's rise to power was due to his own boundless ambition and the assistance of his fleet, which in combination with support from Bohemond of Antioch and his nephew Tancred, put pressure on Godfrey, who needed allies and was quickly finding his power base diminishing and having to rely more on Daimbert's military forces. Over the course of Godfrey's single year as ruler, he came further and further under Daimbert's thumb, and in an astonishing admission of this weakness, consented to the argument that Jerusalem belonged to the patriarch by right of his spiritual position. It was agreed that as soon as Godfrey had conquered other local cities the transfer of power would be made, or at the latest upon his death if he died without heir. ${ }^{107}$ While this seems fantastic, Godfrey may have had plans to create his own distinct kingdom, utilizing the powerful Daimbert as an ally and shifting the responsibility to protect the holy city to him. It might not have been a bad plan, but Godfrey's sudden death caused a chain

\footnotetext{
105 John G. Rowe, "Paschal II and the Relation between the Spiritual and Temporal Powers in the Kingdom of Jerusalem,” Speculum 32 (1957): 473-475.

106 WT, 402-403.

107 Hamilton, Church, 53-54.
} 
reaction of events that forever dashed the patriarch's ambitions. As Hans Eberhard Mayer states, Daimbert's greatest mistake after his political victory, was in remaining absent from Jerusalem after Godfrey's death. ${ }^{108}$

According to William of Tyre, legally the Latin Kingdom's cities should have passed to the control of Daimbert, as Godfrey had promised. ${ }^{109}$ The Lorraine faction which had remained loyal to Godfrey and particularly members of his household, fully understood that his agreement with the patriarch was predicated on the issue of natural heirs. He had never declared for Baldwin, his younger brother in the north, or his older brother Eustace back in France. However, the retention of the Tower of David under the leadership of Count Garnier de Gray, upset the political ambitions of the patriarch. The count was a staunch supporter of the House of Bouillon, and his orders carried greater weight than Godfrey's agreement with the archbishop. Garnier sent an urgent message begging Baldwin to come take up the throne, while he and other former followers of Godfrey kept the patriarch's men at bay. Baldwin did not delay.

The acceptance of Baldwin by the leading majority of the kingdom put Daimbert's claims in the shade. Alan V. Murray has even suggested in an article on the Domus Godefridi, that in fact Baldwin had been named Godfrey's heir since their departure from Lotharingia in 1096, which questions even further the patriarch's right to challenge his succession to the kingship. ${ }^{110}$ Daimbert did try to rally support by composing a letter to defend his claim, but this backfired on him when it was later used to prove his complicity

\footnotetext{
108 Mayer, Crusades, 67-69.

109 WT, 417-418.

110 Alan V. Murray, "Daimbert of Pisa, the Domus Godefridi and the Accession of Baldwin I of Jerusalem," in Clermont to Jerusalem: The Crusades and Crusader Societies 1095-1500 (Turnhout: Brepols, 1998), 81-102.
} 
in an attempt to stir up a Christian civil war. ${ }^{111}$ However, confident that his position was supported, Baldwin took his first raiding trip just six days after arriving in Jerusalem, giving the patriarch time to conclude that he had been outmaneuvered and that it was time to come to terms with Baldwin. The result was a moderate rapprochement created by some of the "wiser minds," according to Fulcher, in which the new king and the patriarch were in theory reconciled. ${ }^{112}$ The ceremonial crowning took place in Bethlehem at Christmas in 1100. Baldwin swore to honor and defend the Holy Sepulcher, intimating his plan to rule rather than to serve. ${ }^{113}$

The turbulent relationship between Baldwin and Daimbert could have been resolved after the reconciliation, however the patriarch refused to see his role as a supportive partner to his new ruler. Daimbert well understood the poverty of the royal treasury, but the patriarch insisted on using the wealth of the Church for himself and manipulated individuals through bribery. He made a few special payments to Baldwin, attempting to mend old grievances or to cover new ones, but that was not fundamentally what the king wanted in a patriarch. ${ }^{114}$ Baldwin needed a church leader that was not just amiable to his leadership, but one that supported the crown with strong financial backing, and often at that! Baldwin appears through the texts to be willing to tolerate most levels of corruption in his churchmen - as he would show with the return of Arnulf of Chocques to the patriarchate in 1112 - as long as they assisted him in protecting the realm. This was not altogether exceptional in the politics of medieval Europe.

Jonathan Riley-Smith, in his short essay on the Latin clergy in the First Kingdom

\footnotetext{
111 WT, 419-421.

112 FC, 147.

113 Murray, Dynastic, 94-97.

114 AA, 568-569.
} 
of Jerusalem, illustrates an important point when evaluating the kinds of men available to Baldwin for leadership in the Church. With the death of the bishop Adhemar of Le Puy at Antioch in 1098, and the death of Peter of Narbonne, there simply were no Latin clerics of note either for their education or administrative experience remaining in the holy land. ${ }^{115}$ This was one reason that Arnulf of Chocques was elected to the patriarchate in Jerusalem, despite his lack of qualifications. His timely "discovery" of the True Cross was another major reason for Arnulf to justify his claim to the patriarchate, arriving as it did at a crucial time following the election of Godfrey. ${ }^{116}$ It should be added that men like Daimbert and Arnulf stand out from the record partially because they are mentioned frequently and were in positions of influence. It would appear that many upstanding individuals simply do not get mentioned, or have no contemporary evaluation of their performance put on the record. For instance, we know nothing of the actual work of Fulcher of Chartres and how effective he was in carrying out his jobs as a chaplain and a canon of the Church of the Holy Sepulcher.

Baldwin's eventual break with Daimbert arose over the patriarch's confiscation of funds that were sent for the defense of the kingdom by Roger of Apulia. ${ }^{117}$ One third was to be given each to the Church, to the kingdom's defense, and to the Hospital of St. John in Jerusalem. Arnulf, eager it appears to cause a breach in the relationship between king and patriarch, accused the patriarch of embezzlement, which resulted in a trial presided over by Bishop Maurice of Porto, the new papal legate sent by Pascal II. Daimbert was relieved of his office and powers, shortly after Baldwin caught the two men feasting in a

115 Jonathan Riley-Smith, "The Latin Clergy and the Settlement in Palestine and Syria, 10981100," The Catholic Historical Review 74 (October 1988), 543-544.

116 AA, 451-453.

117 AA, 569-575. 
palace apartment. The former patriarch had been trying to win over Maurice with monetary generosity to influence his decision, but the end result was a supposedly eloquent speech by Baldwin regarding the needs of the holy land and his upbraiding words against clerics who hoarded silver and gold, when it could have been used in the interest of the people and their protection:

Day and night you are engaged in feasts, while we are preoccupied by troubles and dangers for the safety of our brother Christians. You gratuitously devote the offerings of the faithful to your pleasures, you disregard our difficulty and need. But the Lord is living! From now on you shall not touch any of the offerings of the faithful, nor shall you any longer fill your stomach from them so luxuriously, unless you undertake the payment of soldiers. ${ }^{118}$

This scene is dramatically represented by Albert of Aachen, and if the words are not fully the king's, the tenor of the speech seems more than obvious in light of Baldwin's military operations against the coastal cities. He fully expected the financial support of the Church, whose traditions, relics and holy places he protected.

Maurice was made guardian of the vacant office in place of the deposed Daimbert while waiting for another man to be elected, the latter retiring first to Jaffa, then to Antioch, where Tancred received him. Maurice might have proved an effective and able patriarch and would probably have been elected to the position, but he died in the spring of 1102, leaving the door to the most powerful Church position in the Latin Kingdom vacant again. Daimbert was able to return with the aid of Tancred to make one more bid for power in the autumn of that same year, but finally a cardinal-bishop, a legate from the pope named Robert of Paris, arrived and found Daimbert guilty of all charges. If we can

\footnotetext{
118 AA, 571. "Vos in commessationibus, nos in tribulationibus nocte ac die pro salute confratrum nostrorum et periculis uersamur. Vos gratis uota fidelium in deliciis uestris applicatis, angustias et penuriam nostram ignoratis. Sed, uiuit Dominus, amodo de omni oblatione fidelium non contingetis, nec de hac uentrem uestrum ultra tam delicate implebitis, nisi milites in conuentione solidorum susceperitis."
} 
believe the chronicle of Albert of Aachen, there was no distance too great for many prelates who came to secure Daimbert's fall. He argues that Daimbert's enemies quite literally came from all corners of the crusader states to condemn him. Arnulf was restricted from the office at this time because of his reputation for corrupt practices, and for once a man of whom no real complaint surfaces was elected patriarch, a simple man of faith according to Fulcher, named Evremar. ${ }^{119}$

This prelate is particularly memorable as a man of action, and for riding on a horse before the royal army about to engage in the Second Battle of Ramleh. There he brandished the relic of the True Cross and exhorted the men to fight bravely with the help of God. It can be conjectured from pictures like this that he was a man suited to the scene of battle, for he is mentioned several times in connections with them, but there is nothing to support that he was a completely unlearned individual, as suggested by Fulcher's comment. It may very well be that such a turn of phrase offered a modest note of praise, for some of Evremar's predecessors to the patriarch's throne were duplicitous, venial men. Evremar would in his turn be removed from office as well, though he was rewarded with an archbishopric in Caesarea, which suggests that the king had been pleased with him and did not want to completely dishonor a loyal man. The see of Caesarea was second only in importance to Jerusalem, within the ecclesiastical offices of the kingdom.

The leading complaint against Evremar was that he was not considered competent to conduct the affairs of the Church in so important a position. ${ }^{120}$ What exactly did this mean? Scholarship on the question seems to have assumed that this was really an issue of his being a nonentity, linking the problem to a question of prestige and recognition

119 AA, 653-659; Hamilton, Church, 56.

120 WT, 466-469. 
across Christendom. ${ }^{121}$ The new patriarch was also from Flanders, and thus likely to be a partisan of the Bouillon-Boulogne party. Yet another possibility, is that perhaps Evremar was not as effective in amassing treasure that could be put at the disposal of the king. Certainly none of the contemporary sources accuse the patriarch of corruption. Upon his death in 1129, Evremar still maintained the highest respect from his fellow crusaders as a man of unimpeachable character, and a well respected position of ecclesiastical authority. Perhaps the truth of the matter was simply that he in fact did facilitate the use the Church offerings, channeling it towards charities and services for pilgrims, and not into the coffers of the king's treasury. ${ }^{122}$ This problem is never cleared up in the texts, and as stated already the king did not seem to have rejected Evremar out of hand. He did not protest when the new papal legate, Gibelin, Archbishop of Arles, appointed the latter to Caeserea in 1108 after his deposition from the patriarchate. ${ }^{123}$

Evremar continued in his position long after the disputes engendered during the time of Baldwin I, surviving in his archbishopric to march with Baldwin II in battle in 1119, and in later sources he features prominently as the bearer of the True Cross in battle. ${ }^{124}$ It was Evremar who stood in the gap between a furious Baldwin and the Italian allies who slaughtered the inhabitants of Acre. Diplomatic negotiation was obviously a very important role of the patriarch, which is not as obvious in a reading of the texts, which tend to focus on the more scandalous nature of the church leadership. Crusader scholarship would be much benefited by a study of this man and his influence on the king

121 Hamilton, Church, 56-59.

122 Hamilton, Church, 114-115.

123 Runciman, A History, 84-85.

124 William the Chancellor, The Antiochene Wars, trans. Thomas S. Ashbridge and Susan B. Edgington (Brookfield: Ashgate Publishing, 1999), 153-154. 
of Jerusalem.

Gibelin of Arles was then appointed by Baldwin to the patriarchate and served for four years before he died and left the office vacant. After the loss of yet another valuable churchman who had come to the east to settle an issue and then found himself acting as guardian of the most important metropolitan seat of Christendom other than Rome, the clergy decided to bow to the inevitable and chose a man who had been with the crusaders from the beginning and who now had arguably the most experience in the politics of the Latin Kingdom. Arnulf of Chocques was at last elected patriarch again and stayed in that position from 1112 until his death in 1118. It would appear that his scheming and intrigue had paid off in the end, but Steven Runciman makes the valid point that Arnulf was the best ally for Baldwin in that he was effective in rallying support for the king's causes, and assisted in consolidating the new conquests through his ecclesiastical influence. Doubtless he understood best the king's need for money, and by utilizing giftgiving at the right time and recognizing that Baldwin could be a staunch supporter if he was respected, managed to be elected a second time and survived in spite of his dubious lifestyle. ${ }^{125}$

The summation of Baldwin's difficulties in keeping and maintaining a patriarch he liked, was not just a matter of money or assistance in ruling a kingdom, it was fundamentally a matter of control. Daimbert had tried to keep the kingdom from him, and then foolishly attempted to keep back Church money in spite of concerns of the kingdom's security. These acts challenged Baldwin's authority in a way that he could not overlook. Maurice and Gibelin had both been capable men sent by the pope and were 125 Runciman, A History, 85-86. 
well suited to the role, which is why Baldwin was content to keep one as guardian of the office, and chose to elect the other. The choice of Evremar by the clergy had also stood because the man was not a threat to Baldwin's authority, and quite compliant. Arnulf, however, was the final choice. Baldwin wanted a man that was completely loyal to him alone, but at the same time ambitious and clever enough to coerce others for his own ends. Baldwin wanted to bring the Church into line behind the throne. ${ }^{126}$ He had deemed it necessary that the churchmen of his lands did not mirror those of the west, becoming manorial lords that challenged the rule of their kings, and on the whole he succeeded before his death, maintaining true power in his own hands, secular ruler though he was.

\section{The See of Bethlehem}

Another example of the king's growing authority was the recognition by the papacy of his important influence in ecclesiastical affairs. Baldwin's role in achieving the recognition of Bethlehem as an episcopal see in the year 1110 clearly demonstrates his ability to convince the Church of his right to make changes even in the spiritual realm. William of Tyre informs his readers that the church of the Nativity had only been a priory of the see of Ascalon until the decision of the king to lobby for its recognition as the seat of a bishop, and includes in his chronicle the edict of the king concerning the elevation of Bethlehem. ${ }^{127}$ Baldwin's proclamation is not found in either Albert of Aachen's work, or that of Fulcher of Chartres, although William presents it as being widely known and

${ }^{126}$ Walter Fröhlich, The Letters of Saint Anselm of Canterbury, vol. 3 (Kalamazoo: Cistercian Publications, 1994), 36-37. It is uncertain whether Anselm's letter to Baldwin in 1104 or 1105, was of a friendly reminder to do right by the Church, or brought on by reports he may have heard concerning the dispute between Daimbert and the king. A careful reading of the letter suggests that it was a cautionary letter in the absence of any certain knowledge on the part of Anselm, regarding what was actually happening in Jerusalem.

127 WT, 481-484. 
signed by important representatives of the court.

The omission of this information is strange, unless one considers that Fulcher's narrative purposefully focuses on the king's military activities to the exclusion of his domestic involvement with Church policy, which does not seem to have been his main concern and perhaps was information he wanted to suppress. Albert's omission in mentioning the elevation of Bethlehem seems odd as well, as it would have occurred during the same period in which Baldwin was involved in political disputes in Tripoli and Syria, and might have reflected all the more clearly the power and authority of the king over the political arena of the Kingdom of Jerusalem. This is at least one possible reason for the absence of the charter in his work. It is hard to escape the conclusion that both Fulcher and Albert felt it was not so noteworthy, and perhaps that it reflected poorly on the state of affairs in the early years of the kingdom's history. If this is true, it would be because the king of Jerusalem was taking the prerogative of the Church into his own hands, to the detriment of papal authority, a fact which was not quite so important fifty years later when William of Tyre wrote about it. ${ }^{128}$ The charter is included below to give the reader the original text to consider with my following points, and because it is the longest record of Baldwin's purported words.

The race of the Franks, inspired and admonished by divine grace, has liberated from the desecration of the infidels the holy city of Jerusalem, so long oppressed by the pagans - Jerusalem, the city where our Savior by His own death destroyed death, which first laid hold on the human race through the sin of our first parents. This city, worthy worshiper of God, was invested by this nation on the seventh day of June, and on July 15, because God fought for it, it was captured.

In the year of our Lord 1100, under the inspiration of divine will, the clergy and Raymond of St. Gilles, the two counts, Robert of Normandy and Robert of Flanders, Tancred, and the other principal men with all the host of the Franks, 128 Rowe, "Paschal II," 489-490. 
decided that my dearly beloved brother, the most pious and merciful Duke Godfrey, should preside over the captured city. But on the third day after the expiration of the first year of his rule, by the will of God, this worthy man of God, the ruler of the city, passed away in peace.

I, Baldwin, who by the virtue of the divine will was chosen to succeed him as the first king of the Latins by the rejoicing clergy, by the princes, and by the people, have looked with discerning eye upon the excellence of the church at Bethlehem, the birthplace of our Lord Jesus Christ and the place where my head received the glittering diadem; and I have resolved to invest it with full episcopal dignity.

For a long time, with sincere heart, I continually pondered this cherished plan. Finally I broached the subject to the distinguished Archdeacon Arnulf and to the chapter at Jerusalem and earnestly begged them to consult with me over the matter. They acquiesced in my just request and resolved to go to Rome to discuss this matter as well as that of the see of Jerusalem, which at that time was, as it were, without a father. Accordingly, the Archdeacon Arnulf and Archard, who was deacon at that time, undertook this embassy. They proceeded to Rome and, by the help of the Holy Spirit, obtained honorable assistance in respect to both matters from Paschal II, the pontiff of the church universal. They then came back to Jerusalem.

After their departure, Pope Paschal sent to Jerusalem Gibelin, the archbishop of Arles, a man of brilliant intellect and most virtuous life, to whom, in the presence of Arnulf and Achard, he had assigned the mission.

Most joyfully was he received by me, by the clergy, and by the people; and, in virtue of the orders received from Pope Paschal, with my good will and the assent of the chapter at Jerusalem and the favor of the whole council, he dispensed all matters according to his own judgment. He decreed that Aschetinus, an illustrious man presiding over that same church and also precentor therein, whom the chapter at Jerusalem, at my express desire and that of my chief men and the people, had chosen as bishop of Ascalon, should become the first bishop of Bethlehem. Furthermore, at my own desire and command, he made the church at Ascalon subject to the see at Bethlehem with parochial right.

Finally, I, Baldwin, by the grace of God first Latin king of Jerusalem, have joyfully and with all my power confirmed all his acts. I have also given of my own will and have granted absolutely to the bishop and to his successors to hold and possess the city of Bethlehem, which I had already granted to the church for the salvation of my own soul and that of the most merciful duke, my brother Godfrey, and those of all my relations.

I have also granted and conceded to him a village in the territory of Acre, called Bedar; also another in the territory of Nablus, named Seylon; and another near 
Bethlehem, which is called Bethbezan; also two villages in the territory of Ascalon, namely Zeophir and Caicapha, with their dependencies.

I have also made the aforesaid church free from the accusations with which the church at Jerusalem has troubled her, on the subject of the lands and vineyards in the suburbs of Jerusalem, which are a part of my domain.

Moreover, I decree that if any cleric or layman induced by most wicked avarice shall presume after my death to violate that which at my petition has been confirmed with the aid of the Holy Spirit (concerning the church at Bethlehem, illustrious as the birthplace of our Lord and Savior) by Paschal the supreme and revered pontiff of the Roman church, through the agency of Gibelin archbishop of Arles, his legate, that man shall be held guilty of the charge of invasion; and, unless after due warning he shall withdraw from his purpose, he shall be severely dealt with and expelled absolutely from our realm.

Moreover, if any one of my nobles, or knights, or burghers, inspired by the spirit of God, shall desire to give of his possessions to this same church for the good of his own soul and those of his relatives, I grant that he be free to carry out his pious wish and that the donation be legal and be a perpetual charge on his property.

This act of concession and the account of the things done has been made and our signature confirming it given in the year 1110 of the Incarnation of the Lord, in the third indiction; Pope Paschal II presiding over the Roman church; Gibelin, archbishop of Arles, vicar of the apostolic see, being patriarch-elect of Jerusalem. ${ }^{129}$

With the opening of the edict, Baldwin presents a short summary of the history of the success of the First Crusade, the victory over the enemy, and the succession from Godfrey to himself by the will of the people, without any mention of the dispute with Daimbert. He was in effect made king by God and the people. In recognition of that mandate, he turns to the subject of the birthplace of Christ, which was the site of his own coronation with a "glittering diadem."130 These two events are spoken of in tandem, and the implication is clear: Bethlehem should be honored with episcopal status, because of these two events. Its status was symbolic rather than essential, given the small size of

\footnotetext{
129 Mayer, ed., Die Urkunden, 159-164; WT, 481-484.
}

130 WT, 482. 
Bethlehem as compared to Ascalon, and the honor served to commemorate Baldwin's kingship as much as recognized the sacredness of the city for Christianity.

The edict then proceeds to depict a king tortured by the need to do something for the Lord out of a fervent heart, and the eventual admission of his cherished desire to the sympathetic Arnulf of Chocques and the chapter at Jerusalem. Baldwin sent a delegation to Paschal II in Rome, led by Arnulf, to achieve this aim, and yet again Fulcher does not mention any dispute regarding the deposition of Daimbert as patriarch or the conclusion that Evremar was not the right person for the job. Gibelin of Arles, the papal legate, is said to have been sent to address this specific request regarding Bethlehem. All went well, and Gibelin decreed that Aschetinus, then bishop of Ascalon, should henceforth be the bishop of Bethlehem. This was done by the will of the church in Jerusalem and the pope's legate.

Then the real architect of the project comes forth. Baldwin claimed to not only have decreed the transfer of the episcopal status from the church of Ascalon to Bethlehem at his own desire and command, but that it was he that joyfully confirmed the acts of Gibelin. Baldwin makes no bones in the charter about the fact that he is the one who empowers the decisions of the Church to assign spiritual leaders, and it is he again in the next paragraph who provides for the well-being and prestige of the new bishop by giving lands, villages, and protection privileges. Baldwin was to be the primary patron, for this establishment was a memorial of his rule. ${ }^{131}$

The charter's final section is an invitation by the king to his nobles and the

131 WT, 482-483, Hamilton, Church, 59. Hamilton asserts that the former position of Bethlehem was as a shrine church, and that the translation of the see was probably accomplished in 1108, with the formal endowments ratified in 1109-1110. 
kingdom's burghers to shower gifts upon the newly elevated church, an act as pious as serving the personal desires of the king, and perhaps an implicit test on his part to see who regarded his wishes important enough to act upon. A list of witnesses and their signatures are recorded, after a final note on the fact that the king's own personal signature had confirmed the concessions. ${ }^{132}$ The point is inescapable that the king orchestrated everything from first to last, being careful to respect the Roman See in a way that appears to honor any possible reservation on the part of the Church, but in actuality pushed through his wishes on a personal issue without opposition.

The transference of the cathedral status had more to do with the power of Baldwin in his realm and the decision to memorialize it than anything else. Reflecting on his victory over the ecclesiastical authority at the time of his coronation, Baldwin set Bethlehem apart and established it as the place upon which authority over the kingdom would be drawn by future kings, such as his immediate successor Baldwin of Bourcq. Though the papal authority of Rome over Jerusalem and its autonomous patriarchs had become much stronger, as Rowe points out in his insightful article, ${ }^{133}$ the state of the Latin Kingdom between secular and spiritual authority was far less balanced than in contemporary western Europe. The east was still a frontier despite its central importance to Christianity, and Baldwin well understood his advantage in power over the local church.

\section{Baronial Recognition}

One of the least studied questions regarding Baldwin's rule concerns his

132 WT, 484.

133 Rowe, "Paschal II," 490. 
recognition by the barons of his kingdom, and the princes of the other Latin crusader states in Syria. Why he remained the unchallenged head of the Kingdom of Jerusalem after the fall of Daimbert, and acted as an authoritative arbitrator in civil disputes among the crusaders, are questions that lead to an evaluation of his recognition as king by his peers. The post-crusade East was a distant land on the edges of Europe that could have remained estranged from Christendom under the crusader princes. In many ways this was the case early on, with several of the crusade leaders carving out lordships, but the Kingdom of Jerusalem itself remained firmly in the hands of one man for nearly twenty years, which reflected on Baldwin's ability to lead his followers.

Godfrey of Bouillon was dead within one year and three days of his election, which was soon enough for almost all the First Crusade leaders to have been present and capable of being chosen king, especially the elderly Count Raymond of Toulouse, who had initially formerly "declined" the crown, but who might have reconsidered it in 1100 . In fact, the old warrior from Provence made no move to return to his former lands, but had begun campaigning for his own principality in the east. John and Laurita Hill argue that Raymond was still on crusade, and that his actions demonstrate a man fighting to the end for ideals as well as profit. ${ }^{134}$

This argument seems to hold up in light of Raymond's return journey to Constantinople to meet Alexius. He was one of the few leaders who had not compromised his earlier oath to the emperor. From that point, the next recognized ${ }^{134}$ John H. Hill and Laurita L. Hill, Raymond the IV: Count of Toulouse (Syracuse: Syracuse University Press, 1962), 146-157. The Hills have written the most complete and comprehensive biography to date available on Count Raymond, and it follows a blow by blow account of the count's actions, which are seen in a generally favorable light. The Hills assert in fact that Raymond was the reason the First Crusade ultimately succeeded after the capture of Antioch, when he alone finally began to continue leading the common people on the road to Jerusalem, shaming all the other leaders into returning to help except Bohemond and Baldwin of Edessa. 
activity of the count was his participation in the 1101 pilgrimage led by Stephen of Blois and Hugh of St. Omer, which was redirected to rescue the captured Bohemond, deep in Muslim-held territory near Damascus. The project failed miserably in spite of the count's leadership, and his abandoning of the pilgrims before the catastrophic defeat of their army has often been seen as an act of cowardice or cunning on his part. A more likely explanation is that Raymond understood the foolish nature of his companions, who acted despite his warnings that the goals of both rescuing Bohemond and capturing Damascus, were going to get them all killed. ${ }^{135}$

Raymond returned to Constantinople for a short time, and in the final years until his death in the spring of 1105 , the count set about the task of reducing the city of Tripoli to surrender. During this period he built the famous castle, Mount Pilgrim, to maintain pressure on the city. He never did fully establish his own princedom, but left it to his heirs to carry on the work and to eventually build the County of Tripoli. In all this, though, he never challenged Baldwin as king, and in fact was responsible according to Albert of Aachen for giving warning of the treachery of Daimbert, who had sent a letter to Bohemond asking for assistance against Baldwin's advance and claims on the holy city. ${ }^{136}$ On the one hand it may have been that Raymond simply did not have the manpower to make a successful bid for the throne, having lost men, like all the other leaders, after the crusade's goal of liberating Jerusalem had been achieved. Perhaps another answer is that the old warrior had decided to wash his hands of the other men and their doings, by whose vote he had lost the crown in the first place. Regardless of his personal feelings, at least a recognition of Baldwin's claim and some neutrality can be 135 Mayer, Crusades, 77-81.

136 AA, 523-525; WT, 419-421. 
argued to have existed between the king and the count.

The activities of Bertrand and William-Jordan, Raymond's illegitimate son and nephew respectively, provide an insight into the power politics that were an active part of crusader occupation in the holy land. Both men felt they had a valid claim to the County of Tripoli, and Baldwin was asked to mediate between both parties. Steven Runciman is right in his evaluation of the settlement of 1109 as a great triumph for Baldwin. ${ }^{137}$ His advocacy of the rights of Bertrand to inherit from his father Count Raymond versus the claims of William-Jordan, supported a claim of hereditary right which he would naturally have championed due to the similarities with his own election. There was also the fact that Bertrand was astute enough to understand that he could not survive on his own in the projected County of Tripoli, whose titular city had not yet been conquered, without support from a local power magnate like the king himself. Baldwin stood nominally for the conservative establishment that had always valued Jerusalem, while Tancred, who was acting as regent of Antioch, came to back William-Jordan. He had been invited to support the counter claim of William-Jordan early on, but was forced to back down from the king owing as much to the military backing of Baldwin, as well as the king's recognized prestige. Bertrand got control of his father's county, and would inherit the cities that William-Jordan held, upon the latter's death.

There was one dark stain following the proceedings; namely that the final provision went into immediate effect. Soon after the settlement, the rather timely death of William-Jordan due to an arrow fired "by accident," remains a point of embarrassment in the crusader chronicles. Our three major sources for the reign of Baldwin, William of

137 Runciman, A History, 67-70. 
Tyre, Albert of Aachen, and Fulcher of Chartres, have nothing to tell modern scholarship except to suggest that in a dispute between two squires, William-Jordan was cut down by a freak accident, similar to the arrow that brought down William II of England while on a hunting expedition. Bertrand was rumored, according to William of Tyre, to have been the one behind the death, but gives no proof one way or another. ${ }^{138}$ William-Jordan's death was useful in establishing right away a sole ruler of the County of Tripoli, after which Baldwin and Bertrand successfully captured the city, and this newly established ruler provided a strong support for Baldwin's activities in the north of his kingdom. If Baldwin was at all complicit in what would appear to be a successful assassination, the chroniclers are unusually silent in making accusations, for in fact Baldwin was the only one to really benefit from the final chapter of the 1109 dispute. A friendly buffer state to the north with the addition of another large port city could only help his plans for stabilizing his own kingdom. This was yet another fortunate coincidence for Baldwin.

Bertrand of Tripoli was not in any way a serious rival for the crown. He was a newly arrived man and compared with Baldwin, inexperienced in the politics and warfare of the east. However, Bertrand's Provençals were not a minor force in the east, and Baldwin appears to have looked to him as a valuable ally when it came to taking the fight to enemies along the coast or in the vulnerable northern border of the Kingdom of Jerusalem. Bertrand for his part remained completely loyal to the King of Jerusalem after the issue of his inheritance was brought to a close, Baldwin found a supporter and ally.

Thus the only other serious contenders for the crown of Jerusalem in 1100 would have been the two Norman leaders, Bohemond and Tancred. The former had the

138 WT, 476. 
principality of Antioch under his sway more than 200 miles to the north, but that cannot exclude the possibility that he had designs of his own on the Kingdom of Jerusalem. The correspondence attempted by Daimbert to the Norman leader, could have been the precursor to a form of alliance. The patriarch would arguably have taken the part of the most important spiritual leader in Palestine similar to the pope back in Rome, and established Bohemond as the new "Protector of the Holy Sepulcher" and Godfrey's successor. It was Bohemond's capture in 1101 that removed him effectively from the scene of action for several years, reducing the direct help that Daimbert had hoped for against Baldwin. ${ }^{139}$ As already mentioned in the chronology of events, Bohemond's release from prison in May of 1103 did not result in revenge on his enemies. Bohemond remained in his city of Antioch for almost a year, after kicking his nephew Tancred out for not having raised the money for his ransom. However, having found himself heavily in debt, Bohemond journeyed to Europe in 1106, leaving Tancred once again in charge of Antioch, married the French king's daughter Constance, and following the disastrous war he waged on Alexius I of Byzantium, ended his career in Palestine with the Treaty of Durazzo in 1108. After making concessions which involved the return of Antioch to the Greek empire, Bohemond returned to Sicily to spend his last days, leaving his son Bohemond II as heir to the northern realm of Antioch under the regency of Tancred, who did not honor the agreement of his uncle, but maintained Antioch himself for Bohemond's son and heir. ${ }^{140}$

Thus the senior Norman leader never had the chance to exercise any claims on the Kingdom of Jerusalem, having been captured by his enemies at the wrong time and 
spending the last few years rallying support for another crusade to the east, while all that time vilifying Alexius I to western audiences. His support of Baldwin's kingship is unknown. Bohemond did, however, have a serious impact on the relationship of Tancred towards the new king, by virtue of his imprisonment. Tancred had been prince of the region of Galilee under Godfrey of Bouillon, and could easily have attempted a bid for the crown, however he was with Daimbert at a siege of the city of Haifa at the time of Godfrey's death, and later chose to watch over the city of Antioch during his uncle's incarceration.

Although the Gesta Tancredi portrays Tancred as the epitome of the perfect knight and the flower of nobility, what is not hidden is the fact that he was always short on men in spite of his desire to risk the odds and bring the fight to far stronger opponents. ${ }^{141}$ As another land-hungry noble looking for the opportunity to carve out a place for himself in the east, he nearly came to blows with Baldwin over the capture of Tortosa during his expedition into Cilicia in 1098. Bad feelings existed between the two men for some time after. Reconciliation did eventually come about, and led to later cooperation between them against a common foe after Baldwin was made king. Perhaps this took place in 1104 after the trial held to assess the accusation made against Daimbert, in which Tancred had arrived with the former as a supporter, or in 1101, as Albert of Aachen says, when the Norman leader went to take up the rule of Antioch. ${ }^{142}$

In some ways Tancred had a greater reason to expect the prospect of being crowned king after Godfrey. He along with his uncle supported Daimbert as patriarch, and with the ecclesiastical backing, could have made a bid for the crown. Tancred was 141 RC, 158-159.

142 AA, 555. 
one of the only leaders of the First Crusade left in the southern kingdom who had taken a very active part in the capture of Jerusalem. Aside from personal valor on the battlefield, Tancred was known as a talented military man just as capable as Baldwin in leading small forces to victory. In many ways the two men had very similar backgrounds and accomplishments.

The question is why he did not challenge the rights of Baldwin. A viable answer seems to lie in the degree of desirability between the two cities, Antioch and Jerusalem. The former was a highly desired prize, and despite the toll the 1097-1098 siege took on it, the wealth of the city and its stability in manpower, could well have been far more attractive to the Norman leader compared to the impoverished and strategically vulnerable Jerusalem. The chronicles all but say that Tancred jumped up immediately and rushed to Antioch to guard it for his uncle, for whom he never actively raised funds for a release. Galilee and Tiberius, which Tancred had acquired from Godfrey, were handed over to Baldwin's care, doubling the size of the new king's territory. ${ }^{143}$

No other serious contender for the kingdom existed during Baldwin's long reign, except for Baldwin of Bourcq, who seemed to have remained completely content in defending his principality of Edessa. Utilizing the services of his cousin, Joscelin of Courtenay, Baldwin of Bourcq fought to maintain his holdings in the north, and was captured by the enemy several times over his long career. An accusation of treachery damaged for a short period the relationship between Joscelin and Baldwin of Bourcq, the

143 AA, 553-555. FC, 137. It is quite possible that Tancred's departure to the north is indicative of the desperate state to which the Latin Kingdom had fallen in the south, undermanned and unsupported by adequate resources. This only highlights the magnitude of the problem faced by Baldwin, and begs the question of whether or not he was truly happier for himself as stated by Fulcher of Chartres over his inheritance, or if he ever wished he had remained in Edessa once arriving in his brother's kingdom 
former being accused of plotting to take over his cousin's county. This caused Joscelin, who claimed innocence, to accepted the lordship of Galilee from king Baldwin in 1113. ${ }^{144}$ William of Tyre argues that the Baldwin I was delighted to have a kinsman of Joscelin's caliber as a military man in his service. ${ }^{145}$ This is just another example of how division within the ranks of Christian princes in the holy land, could destabilize potential power bases for challenging the king's authority. Baldwin almost always benefited from these internecine conflicts.

\section{Politics, Profit, and Personality}

Alan V. Murray has recently argued that the king ruled his kingdom in a style that maintained all the power for himself, while subsidizing his men and followers via money fiefs. The minor nobility that guarded the cities of the kingdom were not political players of any consequence. Yet Murray argues that the king was not all-powerful and was under pressure to conform at times to their wishes. The example that comes foremost in Murray's argument, is related to the issue of succession, and the king's loose marital arrangements for profit. While such cases do demonstrate baronial pressure on the king, it is evident in Baldwin's action that his personal desires and choices held the day. ${ }^{146}$

Having lost his first wife Godhilde in 1097, Baldwin took as a wife Arda, a daughter of a wealthy Armenian noble, during his period of time as count of Edessa in 1098. This wife, who had not brought him the profit that he may have calculated a union

${ }^{144}$ Robert Lawrence Nicholson, Joscelyn I, Prince of Edessa (Urbana: University of Illinois Press, 1954), 46-51. Nicholson performs a real service in tracing all the threads of information related to Joscelin and putting them into a solid narrative of his activities, bringing to light an important player in crusader politics that is still little studied.

145 WT, 497-500.

146 Murray, Dynastic, 115. 
with her would bring, was put aside shortly after his accession to the throne. Baldwin had not received the promised dowery from his Armenian father-in-law, and after his departure from Edessa, he no longer needed to court the Armenian nobility as allies. Baldwin then negotiated a third marriage in 1112-1113 to the wealthy Adelaide, widow of Roger I, count of Sicily. The marriage was of great benefit, in the form of cash that the bride brought to Baldwin and his kingdom, but the Sicilian negotiators were insistent that if Baldwin should have no heirs with his new wife, the kingdom would go to Roger II, who had just reached his majority. ${ }^{147}$

It is important to note that at this point in his life, Baldwin was around fifty-three years of age, and childless. The chances were very likely that he would have no children and that the Bouillon-Boulogne dynasty would come to an end with him. Recent scholarship has suggested that after three marriages with no children being produced, Baldwin may have been homosexual. ${ }^{148}$ This revisionist hypothesis rests entirely on a section from William of Tyre's work that evaluates the physical and moral qualities of Baldwin, using the archbishop's comment that Baldwin "struggled in vain against the lustful sins of the flesh," to suggest his sexual preferences. ${ }^{149}$ While offering a possible explanation for Baldwin's childlessness, the fact remains that if it was true, the Church was willing to turn a blind eye to, from their perspective, an obviously moral outrage. In addition, William of Tyre mentions that the king was circumspect in his sin so that many were unaware, yet for William to be writing about the nature of Baldwin's promiscuous behavior almost fifty years later reveals that it was not completely unknown. The fact is

147 Murray, Dynastic, 115-116.

148 Jonathan Riley-Smith, The Crusades: A History (London: Yale Nota Bene, 2005), 94-95; Tyerman, God's War, 200-203. 149 WT, 416. 
that Baldwin may not have been able to have children. Despite his extra-marital activities with other partners, who should be assumed to have been women, no heir appears after his death, just as in the case of his childless brother Godfrey. It should be noted that the older brother, Eustace III, had only a daughter himself, fortifying the position that perhaps the family line was in serious danger from infertility.

Thus when Baldwin was dying at the end of March 1118, the men around him wanted to know who should be elected king after him. He had divorced Adelaide in 1117 after barely surviving a severe illness in 1116. The patriarch Arnulf was the one to tell the king that his bigamous relationship with the heiress from Sicily was the cause of his sickness. (Baldwin had not actually divorced his second wife, Arda.) Murray suggests that the nobles had used the opportunity to put pressure on the king to divorce his third wife, fearing lest Roger II be made an absent ruler of their lands. In light of the subsequent career of Roger II in forging the Kingdom of Sicily, this might not have been a bad thing for the Kingdom of Jerusalem. ${ }^{150}$

Baldwin had not designated anyone to fill his position up to the point of his death. Baldwin of Bourcq had arrived fortuitously in time to be taken as a serious candidate, thanks in part to the suggestion by the dying Baldwin that if his brother Eustace was unwilling to return to the holy land after a nineteen-year absence to take up the reigns of power, then the younger relative from Edessa should be chosen. ${ }^{151}$ Murray feels that this was an unpopular decision among the nobility, and that perhaps a secret meeting had already been planned for that year for the two Baldwins to discuss a plan for the

150 Donald Matthew, The Norman Kingdom of Sicily (Cambridge: Cambridge University Press, 1992). An informative work on the nature of the Norman ambitions in Sicily, the papal politics, and the career of Roger II, whose potential as a ruler is well covered in this work.

151 AA, 867-869. 
succession. ${ }^{152}$ As complicated a picture as the succession seems to be, there is the very real possibility that Baldwin had simply not planned for the transfer of power.

Throughout his career, Baldwin did not groom any potential successor that would obviously fill his role in the future. The lack of children and his advanced years did not necessarily mean that he had ceased to try to produce an heir; indeed he might still have expected one. It would appear that instead, Baldwin had concentrated power in his hands to the exclusion of a second in command, and that if anything, he had only planned to have the kingship given to someone of his family line if he had no children. Eustace would have been a direct heir, and Baldwin of Bourcq was the second closest member. It is noteworthy that he mentioned both men by name to his vassals and aides just before death, suggesting that he had been reconciled to the idea beforehand and left any further preparations for the future to chance. However, the nomination of both men by Baldwin suggests that he was giving his order of preference, not asking but telling his vassals what their choices were. As opposed to Murray's suggestion that the king was not allpowerful, I would argue that his decisions and wisdom were routinely recognized by his men both out of fear, and also from his track record of getting things accomplished for the Latin Kingdom. Such a reputation would have weight in the matter of a recommendation.

\section{The Manpower Quandary}

Baldwin's last but not least important contribution to the effective administration of his kingdom was his attempt throughout his reign to maintain population levels in his

\footnotetext{
152 Murray, Dynastic, 117.
} 
cities. Jerusalem is the location which appears most frequently, but it should be argued that his interest in preserving his subjects, whether they were of Latin, Greek Orthodox, Syrian Christian, or Islamic background, was an ever prevalent concern. ${ }^{153}$ Though it might appear that the crusaders were marginally unaware of the need to maintain a working population in order to support their armies, and were prone to slaughter everyone not a Frank, I would suggest that the evidence presented by the chroniclers demonstrates Baldwin as a conciliator, and to a degree, a peacemaker. To this end he was interested in maintaining his manpower for secular reasons; that is for building a vibrant, economically prosperous kingdom. This appears to outweigh any spiritual concerns as far as he was concerned, for non-Christian populations continue to be present all throughout his reign and his cities. This position finds support in recent evaluations of the situation regarding Frankish ruled areas, and their interactions with the Islamic communities that continued to remain among them. ${ }^{154}$

The crusaders were not unaware of the Syrian Christian groups that co-existed with their enemies in the cities of east. ${ }^{155}$ Many Greek Orthodox priests maintained their religious practices and independence, through the patronage of the emperors of Byzantium, notably in Jerusalem. While sometimes misidentified as Muslims by the Franks, the Christian sects in general assisted the crusaders as fellow if distant brethren in the faith, acting on diplomatic missions and as translators when needed by the westerners, who of course did not speak local languages like Arabic. Thus help from some of these groups was welcome to the army of the First Crusade. The Armenian elite in particular

\footnotetext{
153 Runciman, A History, 100-101.

154 Ellenblum, 3-11, 36-38.

155 Hamilton, Church, 1-3.
} 
had certain appeal due primarily to their willingness to marry their well-born daughters to the French and German nobility. Baldwin was a perfect example of this sort of collaboration, having married Arda, who was an Armenian princess. ${ }^{156}$

Baldwin was quite practical in his utilization of the native populace in spite of his western upbringing; however, it must be pointed out that he spent the first two years of his rule in northern Syria from 1098-1100, in control of a city and territory encompassing both Greeks as well as Syrian Christians. ${ }^{157}$ No mention is made in the chronicles of Muslim inhabitants in the County of Edessa, though doubtless there were, but the Lotharingian force that Baldwin led was a small minority compared to the native population. With observation, Baldwin would have seen that the wealth of the city rested on these very people and that disturbing them unnecessarily would have upset his own prosperity. Food was abundant enough to send to his brother Godfrey at Antioch, and the treasure of Thorus I, whom he replaced as ruler, was put at Baldwin's immediate disposal. From what can be deduced from the chronicles, Baldwin did not pursue a xenophobic principal of purging his territory of non-Christian people, or overtly hostile behavior towards eastern Christians. His attitude towards the Greek Orthodox within the holy city is a good example of this.

The first year of Baldwin's rule in Jerusalem during Easter of 1101, the chapter of the church of the Holy Sepulcher wanted to exclude any but the Latin priests from the services being held in this most important religious center. Baldwin acquiesced in the removal of the other groups, but when the miracle of the Holy Fire failed to take place, in theory because the Greek prelates were not there to make sure it happened, the Latin king 156 Murray, Dynastic, 61-62, 90.

157 FC, 88-92. 
had to take this as a hint to restore the former to some position in the church. Could the miracle of the mysterious lighting of a lamp not be accomplished by the Latins? Of course it could have, with a little ingenuity. Instead the king took the stance that it was indeed a sign of God's displeasure for the ousting of the Greeks, and he took the point of view that some restoration should be made for the eastern church. ${ }^{158}$

On the one hand Baldwin had to maintain good relations with the source of support behind the Greek church, the emperor himself, and his successors, who continued to aid the crusaders by providing a market of goods through the island of Cyprus to the west. There was no need to ruin an amiable relationship. As much as Alexius was occupied by the Turkish incursions and later the war started by Bohemond, the emperor's capacity to attack the relatively weak southern crusader kingdom was not out of the realm of possibility, especially if the eastern church could make a good point for his "justly" taking up arms against the Latin Christians. Leaving the Holy Sepulcher closed to the Greeks would have been quite comparable to the closing of Jerusalem to the pilgrims of the west under the Seljuk Turks, an act that had sparked the First Crusade. As it was, with relatively stable relations between the empire and the Kingdom of Jerusalem, the Byzantines no doubt appreciated a friendly buffer state between them and the Fatimids of Egypt.

The second reason for Baldwin's moderation towards non-Latin Christians was doubtless the fact that the Greek presence was attractive to the colonizers. His nondogmatic position, if anything, encouraged Christian sects to see in Baldwin a potential protector, or at least the leader of a friendly faction in the east. William of Tyre presents

158 Riley-Smith, "Latin Clergy," 551-555. 
in his account on the final years of Baldwin's reign an instance in which the king suddenly realizes, almost as if in a moment of insight, that the city of Jerusalem was barely populated. William goes as far as to say that there are barely enough people to live on one street, let alone to protect the walls. ${ }^{159}$ However, the problem would have been manifest long before the sixteenth year of the king's reign. What is more than likely to have been the case, is that Baldwin's plan to take the coastal cities as an encouragement to induce settlers from the west had not succeeded as well as he had hoped. The almost constant warfare that he had engaged in since his rise to the throne had taken a toll on the kingdom's manpower. The king had no choice but to throw wide open the doors of the kingdom to its native peoples.

As I argued in the previous chapter, Baldwin was not eager to kill the populations of subjugated cities, and he is quite often depicted in the role of a partner with his allies, if not in complete control of them. In the early years of his reign, he exercised less control over the fate of the enemy whose cities he conquered with allies, unless the enemy was willing to surrender or make a deal with him directly. The inference is that Baldwin was always willing to allow his enemy to stay in his newly captured cities for a price, knowing that a strong population was the wealth of such conquests. During his later years, the renown of his success coupled with his growing political acumen, seem to have dictated better bargaining rights for himself at the battles of Beirut and Sidon, than his earlier conquests of Acre and Caesarea.

159 WT, 507-508. 


\section{Conclusion}

Baldwin's domestic policies depict a man whose ambition to be in complete charge of affairs is both impressive as well as understandable. Challenged at almost every step of the way on his rise from a landless third son to king of a new realm in the holy land, Baldwin demonstrated the potential success to be found in crusading, though he was one of the few to achieve it. The initial opposition from the Patriarch Daimbert came as a personal affront to a man who must have come to see himself as led by God or destiny to the very pinnacle of power. Baldwin clearly recognized himself as one of the Kings of Israel, specifically joining the line of King David, leading ultimately to Jesus Christ. This was an honor and a kingdom worth defending. While acknowledging the authority of Rome, he nonetheless controlled the line of patriarchs that passed through his reign, utilizing them as he saw fit. To crown his victory, the raising of Bethlehem to an episcopal see was both a statement of his power, and a memorial to his rule.

As king, Baldwin governed by his actions in the field as well as his moderation at home in the city. A healthy dose of fortunate circumstances continued to buoy his reign as well, removing potential rivals from the scene or bringing timely assistance from the west for his conquests. Yet why he was heading in 1118 to test the defenses of Egypt without naming a successor after nearly dying in 1116, is still unexplained. I have argued that he knew at this point in his life that one of his family members or relatives would be elected in his place, and perhaps he simply was looking for one last adventure. His true motivation may never be known, but Baldwin left to his successor a kingdom that was under tight control and prospering in the relative peace he had won. The kingdom's 
population subjects, both Frankish and indigenous, and their possessions had grown immensely. Ruling over it all, the king had enjoyed almost unchallenged power 


\section{Chapter 4 - Interpretation of a King}

\section{The Epitaph of King Baldwin}

When the king died the pious race of the Franks wept, For he was their shield, their strength, and their support.

He was the right arm of his people, the terror and adversary of his enemies,

The mighty leader of his country, as was Joshua.

Acre, Caesarea, Beirut, and Sidon also,

He took from the impious native foe.

Afterwards he added to his rule and subjected to his authority, The lands of the Arabs or at least those which touched the Red Sea.

He captured Tripoli and with no less might took Arsuth, And likewise performed many other honorable deeds.

For eighteen years the king bore rule,

Then passed to his fate as he was fated to do.

Sixteen times had Phoebus seen the Constellation of Aries,

When the great king Baldwin passed away. ${ }^{160}$

The reign of Baldwin I of Jerusalem as understood by modern scholars has not

changed much from the interpretations given by his chroniclers, though comparative analysis and archeological work have provided an ongoing discussion about the kingdom and the cities under his leadership. As much as Baldwin's direct control and coercion had an overwhelming effect on the ecclesiastical authority in Jerusalem, the record of him left by contemporary churchmen is generally positive and forgiving. No contemporary historian was more influential in crafting the memory of the king than Fulcher of Chartres. The epitaph that the chaplain composed for the dead king was more than just a record of his deeds and life; it offered a reminder of the significant part Baldwin played

160 FC, 222-223; RHC Oc. 437, "Quum rex iste ruit, Francorum gens pia flevit. Cujus erat scutum, robur et auxilium. Nam fuit arma suis, timor hostibus, hostis et illis; Dux validus patriae, consimilis Josue. Accon, Caesaream, Berittum, necne Sydonem, Abstulit infandis hostibus indegens. Post terras Arabum, vel quae tangunt mare Rubrum. Addidit imperio, subdidit obsequio. Et Tripolim cepit, sed et Arsuth non minus ursit. Pluraque praeterea fecit honore rata. Obtinuit regnum rex octo decemque per annos. Postea fit quod erat, ut quod erat fieret. Sedecies Phoebus Vervecis viserat astrum, quum Balduinus rex obit eximius." 
in the conquest of the coastal cities and the expansion of the Latin Kingdom.

The key to understanding Fulcher's portrayal of Baldwin I lies in the fact that he perceived and eulogized Baldwin as a second Joshua, leading the Franks in a second reclamation of the holy land for the chosen people. This is important because as Gabriele describes with great eloquence, Fulcher and his peers of the late eleventh century, worked in a tradition that accepted an idealized view of the ninth century, dominated by the image of Charlemagne. This encapsulated a glorious past, with legendary material claiming Charlemagne had gone on to capture Jerusalem from the infidels during his lifetime. There was even belief that he would rise from the dead to lead them there again. These stories inspired an acknowledged perception of manifest destiny that was played upon by Pope Urban II in his letters to recruit crusaders all throughout northern Europe. He was attempting to tap into a common identity which led the crusaders to coalesce around a Frankish theme, which was a warrior class of Christ's soldiers leaving their homes for the distant holy city. It was not without reason that many of the First Crusade chroniclers saw the crusaders as filling the footsteps of the ancient Isrealites. ${ }^{161}$

This concept of the past colored Fulcher's narrative, and the entire second book of his chronicle is devoted to immortalizing Baldwin's memory as a great Christian king and leader. This is important because the crusaders who remained, colonizers far from home, needed one, particularly after he was gone. This is why Fulcher focuses on comparing Joshua and Baldwin, highlighting parallels in their leadership, similar conquests in Palestine, and the commonly believed concept that the current inhabitants were impious and not worthy of remaining in their cities. Doubtless this was the kind of comparison

161 Gabriele, Memory, 129-159. 
that Fulcher made during the lifetime of Baldwin, but it was also equally important that his memory after death was held in the same high regard. As will be mentioned at the close of this chapter, the death of Baldwin left a crisis in leadership, and this was a transition that Fulcher made more palatable through his narrative both for himself as well as for those western Europeans that remained in the Latin Kingdom. ${ }^{162}$

The use of the biblical figure of Joshua was not new or unheard of among ecclesiastical writers of the medieval period. Joshua's career, that of taking the Jewish people to Israel to carve out a homeland following the death of Moses, was a widely known narrative. While the biblical book of Joshua from the Old Testament focuses on the divinely instructed conquest of the cities that the Israelites encountered, writers of the First Crusade events made the comparisons between the Latin armies and the Chosen People quite explicit. Guibert of Nogent, for example, felt that the crusaders outdid the ancient Jews in their deeds, ${ }^{163}$ while Robert the Monk made his case from the prophetic book of Isaiah, highlighting the Franks as being the fulfillment of prophesy by God against the pagans. ${ }^{164}$ Justification for the conquest of Jerusalem and the holy places was a developing process after the success of the First Crusade. ${ }^{165}$

To analyze Fulcher's image of Baldwin as a second Joshua, this chapter will take a close look at the major themes of this thesis so far, scrutinizing the information presented by the chaplain and demonstrating that his own personal opinions of the king seemed justified as he observed and recorded the events of his time, almost always at first-hand.

162 Joshua 1:1-9, 1:13-18. English Standard Version.

163 Guibert of Nogent, The Deeds of God through the Franks, trans. Robert Levine (New York: Boydell Press, 1997), 8-9.

164 RR, 51-54.

165 Sylvia Schein, Gateway to the Heavenly City: Crusader Jerusalem and the Catholic West (1099-1187) (Aldershot: Ashgate Publishing, 2005), 35-48. 
Baldwin was an effective leader in his day, and perhaps the reason so little has been written about him stems from the fact that he made very few lasting errors, and that his rule went unchallenged. Contemporaries accepted Fulcher's evaluation, with some modification, and mourned the death of the man who, like Joshua for the Israelites, had indeed carved out a domain for the future of the Latin Kingdom.

\section{Baldwin the Crusader}

Fulcher's understanding of what it meant to be a crusader, a term not yet coined in the medieval world, is not hard to define. If he initially viewed the pilgrimage as a mere journey to the holy land to redeem the captured city of Jerusalem, he soon saw the idea of conquest and settlement as the avowed purpose of the crusaders who remained in the east. To be a crusader was to be a resident of the Latin Kingdom, and to defend it against the Muslim rivals of the Christian king. It should be argued that this change of perception began when Fulcher joined Baldwin's entourage on the latter's expedition into Syria. While Fulcher was part of the clergy and doubtless wanted the crusade to continue towards Jerusalem, the ultimate goal, Fulcher never voices an objection against Baldwin's takeover of Edessa. Instead he incorporates it into the record of Baldwin's fame as a warrior, and as a candidate to replace the Armenian governor, Thorus I.

I would argue that this early lordship role of Baldwin was in some ways edited by Fulcher to bolster the image of the man, after the chaplain had some time to look back on and evaluate past events. As mentioned before, Fulcher does not place the blame for Thorus's death at Baldwin's feet, but he is also unable to completely defend the honor of 
his hero. His only comment by way of explanation, is that Baldwin and his men mourned that they were unable to do anything to save the former ruler, who had adopted him as a son. ${ }^{166}$ Albert of Aachen is explicit in his depiction of Baldwin informing Thorus that the people wanted his blood, but again portrays no attempt by the crusade leader to prevent Thorus' murder. ${ }^{167}$

Why is it that Fulcher stands beside his leader's morally compromising decisions at Edessa? For Fulcher, Baldwin's annexing of Edessa represented the first real example of success in taking substantial territory, and hinted that the coming of the crusaders was welcomed with joy by the inhabitants:

On the following day we resumed our journey. When we were passing by the towns of the Armenians, you would have been amazed to see them coming humbly to meet us, carrying crosses and banners, and kissing our feet and garments for the love of God because they had heard that we were going to protect them against the Turks under whose yoke they had been long oppressed. At length we reached Edessa where the afore said prince of the city and his wife, together with the citizens, joyfully received us and fulfilled their promises to Baldwin without delay. ${ }^{168}$

That Edessa was not a widely known locality from biblical narratives did not make a difference, for it was still a praiseworthy accomplishment. To highlight the fact that it came to the Franks peacefully, due to infighting by the local nobility rather than by siege, had a certain tone of justice about it. The door to Baldwin's rule had been opened by God himself, who could turn the plans of men against their own designers. Such was the case of Thorus I, who hoped to cement his position as ruler of Edessa with Baldwin as 166 FC, 91-92.

167 AA, 175.

168 FC, 91; RHC Oc. 338-339, "Sequenti vero die, iter nostrum resumpsimus. Miraremini, quum ante castra Armenorum transiremus, et nobis obviam cum crucibus et vexillis pro amore Dei humillime procedentes, et pedes nostros et pannos deosculabantur, co quod audierant nos a Turcis eos defensuros, sub quorum jugo tamdiu depressi fucrant. Pervenimus tandem Edessam, ubi princeps urbis praedictus et uxor ejus, una cum civibus suis, gaudenter nos susceperunt: et quod Balduino polliciti fuerant, indilate ei compleverunt." 
his heir and supporter, and yet found himself overthrown anyway. Fulcher does not make any biblical allusions to the easy success that Baldwin found, but it is worth noting that like the city of Jericho which fell to the Israelite army who walked around it, the obstacles to the Franks and their victory seemed to be removed entirely for them by the unseen hand of God. ${ }^{169}$

Compared to his silence concerning Edessa, Fulcher is likewise uncritical of Baldwin's oath to Alexius Comnenus, another unexpected development on the arrival of the crusaders in the east. The nature of the crusade was an evolving issue that was evident to the leaders of the expedition almost immediately, for they had been led to believe that the Byzantine emperor was going to accompany them as perhaps the supreme commander of the army into enemy-held territory. Instead they were expected to swear to abandon designs on the former lands of the emperor, and to return them if the opportunity arose. The failure of the emperor to fill the role imagined for him, left the leadership of the First Crusade to a circle of nobles who often bickered with each other. Disillusioned and perhaps wondering what they had sworn an oath for, the crusaders took matters into their own hands, and Baldwin was one of them.

Fulcher passes by the embarrassing scene of the oath, and the fighting that took place as a result of the egotistical clashes between western and eastern Christians. William of Tyre on the other hand spends an extensive amount of time on the incidents of aggression between the empire and the crusaders, as does Albert of Aachen. ${ }^{170}$ This omission was in no small part owing to Fulcher's recognition that the Byzantines did not become a major player in the war for Christian dominance in the holy land. Byzantium 169 Joshua 6:1-27.

170 WT, 136-151, AA, 73-93. 
held many great wonders in its relics, and its churches amazed him, but the Greeks were no longer claimants worth considering after their dubious negotiation behind the crusaders' backs for Nicaea, ${ }^{171}$ and their abandonment of the Latins at Antioch in their darkest hour. They had once been great and held in high esteem, but Fulcher's narrative gives about as much attention to the eastern empire as he felt it deserved, which was at best a fourth place after the crusaders, the Muslims, and the papacy. The crusaders, and specifically Baldwin, are recognized by Fulcher as the real players in the epic events unfolding in his history.

This evaluation of the Byzantine role in the crusades by Fulcher is of course an unfair one, as historians have realized thanks to a currently wider understanding of the problems posed by the crusaders to their eastern hosts, and the complexities of Greek politics. Alexius had attempted to control the men from the west, which resulted in the failure of communication between both parties. However, had the western leaders been willing to submit to him and to exercise a greater control over their troops, it is possible that more could have been made from their alliance. As it was, the crusader leaders and some of the people beneath them did benefit financially from the emperor, and the information they gained from him about the enemy they were to face proved invaluable. ${ }^{172}$

The conquest of Jerusalem, which Fulcher reports on the testimony of witnesses, marked the completion of the goal that had moved many in Europe to travel thousands of miles through dangerous terrain and to sacrifice so much. Many of the pilgrims then returned; but why did Fulcher stay behind? As Baldwin's chaplain, the chronicler was

171 FC, 81-83.

172 Tyerman, God's War, 109-118. 
ideally placed to see the prospect of a colonization of formerly enemy-held lands. Only a year had passed before Godfrey's death, a year in which as Baldwin's confessor he had doubtless seen the ambitions that could fuel his lord to greater things if given the chance. The opportunity for Baldwin had arrived. Though Fulcher noted that Baldwin spent less time mourning his brother than rejoicing in his inheritance, he makes no further remonstration against the attitude of the king. ${ }^{173}$ Why is this?

On the one hand, Fulcher was not the one to decide the conduct of his peers, nor to stand in judgment of them unless their errors were obvious. In spite of the very personal and informal way in which the chaplain wrote, Fulcher avoids composing a work that is overtly critical of anyone. On the other hand, Fulcher had followed the amazing deeds of Godfrey and Baldwin for several years by this point. He had seen the infidel removed from the holy places with surprising speed and against impossible odds. With the death of Godfrey and Adhemar of Le Puy, he saw a changing of the leadership of the settlers in the land. Baldwin had taken on the leadership role of a second Joshua, compared to his brother, who had been a Moses to his people both in reported piety and inspiring energy. The end of Godfrey's life was seen as the death and reward of a saint:

When the rising sun entered the Sign of the glowing Leo, you rejoicing ascended to heaven borne by Michael the Archangel. ${ }^{174}$

Meanwhile, Baldwin's role as a crusader had ended, and his role as king and leader of a people in a brave new world had just begun.

By comparison to the biblical account, the tribes of Reuben, Gad, and the halftribe of Manasseh, accepted from Moses territory outside the promised land in the book 
of Deuteronomy, on the condition that they would help establish the inheritance of the other tribes in Palestine before settling back down with their families. ${ }^{175}$ The book of Joshua records the valor of these fighting men who eventually returned west and crossed back over the Jordan River. ${ }^{176}$ Fulcher likely saw the similarity of this event when the crusaders who had taken Jerusalem returned to the west, having fulfilled their oaths. That Baldwin did not have to be encouraged by God or the people to "be strong and courageous" was not important, nor was the fact that he was delighted to take up the mantle of his brother. ${ }^{177}$ One book in the history of the west in Palestine had closed with Godfrey's death, but another had opened. The chaplain was no doubt anticipating great things in 1100, and by 1118 he could look back and see that his confidence had not been unmerited.

\section{The King as an Enforcer}

The role of Joshua in the Old Testament was more than just that of the leader who took the Children of Israel into Palestine to conqueror new homes for them, as promised by God. According to the Biblical narrative he was also an instrument of judgment on the 'wicked people' who inhabited the land, justifying the war that brought the tribes of Israel their inheritance. ${ }^{178}$ The journey through the desert for forty years had been brought on by the sin of doubt and the rebellious behavior of the Israelites. When they finally prepared to enter the promised land, Joshua sent two spies in to size up the enemy. These men were told by a common woman of the people, the prostitute Rahab, that the

\footnotetext{
175 Numbers 32:1-42

176 Joshua 4:11-14

177 Joshua 22:1-9

178 Deuteronomy 31:1-8
} 
hearts of the people were melting out of dread because of the Israelite army and Jehovah. ${ }^{179}$ For Fulcher the comparison would have appeared quite appropriate, for all along Baldwin's route to take up his kingship after the fight at Dog River, the Muslim communities continually sent him peace offerings of food and provisions; including Tyre, Acre and Sidon to name just a few. ${ }^{180}$ These were also some of the highlighted conquests mentioned in the epitaph, and thus held significant importance to Fulcher's memory and presentation of the deceased king.

Baldwin was in many ways a perfect model of the Joshua analogy used by Fulcher. Baldwin's journey through hostile territory, Anatolia and Palestine, was comparable to the journey of the Israelites in the wilderness, who had defeated the ruling kings east of the Jordan while under the leadership of Moses. ${ }^{181}$ Contemporaries and later re-writers of the events of the First Crusade, likewise thought in these same terms. Robert of Reims was a later writer who waxed eloquently on the spiritual virtue of the crusaders, while Guibert of Nogent explicitly says that the Franks were far worthier of admiration than the ancient Jews, being led through hardship to Jerusalem, while the Israelite people had a comparatively easy journey on full stomachs! ${ }^{182}$

The death of Godfrey fell hard on the Christians, and the election of Baldwin as a successor brought a certain expectation, namely that he would take up the work that his brother would have pursued had he been granted the years. It was Baldwin's duty to address the issue of the survival of the Latins, but it was not seen that way by Fulcher, who even comments on the smallness of the kingdom at its inception. Baldwin's real role

\footnotetext{
179 Joshua 2:1-11

180 FC, 142.

181 Joshua 12:1-6

182 RR, 79-81. GN, 32, 124.
} 
according to Fulcher, was in bringing the justice of God down upon the unbelievers who defiled the holy places by their presence, and occupied the cities of Palestine in defiance of the coming of God's chosen people. Fulcher protests that he is not daring to compare the deeds of the Franks to those of the Israelites and the Maccabees in his short but jubilant prologue to his chronicle, but to make sure his readers do not miss the point: Although I dare not compare the above mentioned labor of the Franks with the great achievements of the Israelites or Maccabees or of many other privileged people whom God has honored by frequent and wonderful miracles, still I consider the deeds of the Franks scarcely less inferior since God's miracles often occurred among them. ${ }^{183}$

God shows no mercy to the Turk or the Saracen in Fulcher's rendition of the divine assistance to the Franks, for God always shows up in the miraculous victories or the punitive defeats, but the enemy never counts as more than a foil for the works of the devil and as adversaries for the Christians. The vision of the cleric who warned the Christians not to flee Antioch because God was going to save them, was analogous to the appearance of the commander of the armies of the Lord to Joshua. ${ }^{184}$ Fulcher knew that a good argument for such a comparison could be made. Any crusader that remained true to his or her vow, could easily be identified with the chosen people of God.

In this regard, Baldwin is more than a shining example of the crusader ideal. He actively brought war throughout his eighteen years of rule, rarely running from a fight if he were defeated or in danger of losing what small advantage might remain in a tactical retreat. His subjugation of the coastal cities is praised by Fulcher, who shows no remorse

${ }^{183}$ FC, 58; RHC Oc. 319, "Licet autem nec Israeliticae plebis nec Machabaeorum aut aliorum plurium praerogativae, quos Deus tam crebris et magnificis miraculis illustravit. Hoc opus praelibatum aequiparare non audeam, tamen haut longe ab illis gestis inferius aestimatum, quoniam Dei miracula in eo noscuntur multipliciter perpetrata."

${ }^{184}$ FC, 102-103; Joshua 5:13-15. 
in the narrative for the native populations killed, unless they had sought terms with Baldwin and were betrayed by the king's faithless allies. Even in mercy for financial gain, arguably for the benefit of the kingdom, Baldwin was still a judge making the decision to spare the enemy by the right given to him by the Almighty. No one contested Baldwin's right in this, and though Fulcher never actually refers to the king in a judicial capacity, it has to be inferred that the chaplain did not in any way disapprove of the actions of the monarch, even if he does not say so in the text. Fulcher speaks often of the unmaking of rulers by God, owing to their violence and faithlessness, and has his own commentary on the qualification of ruling:

Moreover a king is not made king against the mandate of God, for when he is chosen rightly and according to God's will he is sanctified and consecrated with a lawful blessing. Anyone who receives the kingly power together with the golden crown takes upon himself at the same time the honorable duty of rendering justice. To him certainly as to the bishop in regard to the episcopate can this be fitly applied: 'He desires to do good work who desires to rule but if he does not rule justly, he is no true king.'

How indeed shall one be king who is always conquered by his vices? How does one deserve to be called king if he is always outside the law? Because he does not keep the law of God, his is not obeyed; and because he does not fear God, he shall fear the man who is his enemy. Whoever is an adulterer, a perjurer, or a sacrilegious man, such a one has lost the name of king. ${ }^{185}$

The conquering of cities and armies was God's work, and Baldwin was the right divine instrument.

185 FC, 148-149; RHC Oc. 382, "Rex etiam contra jussa non praeficitur, nam jure et secundrum Deum electus, benedictione autentica sanctificatur et consecratur. Qui quum suscepit regimen illud cum corona aurea, suscepit quoque justitiae obtinendae onus honestum. Cui jure, sicut et episcopo de episcopatu, potest decenter objici: Bonum opus desiderat, qui regnum desiderat. Quod si jure non regit, nec rex est." FC 245-246. "Quomodo ergo rex erit, qui semper vitiis vincitur? Numquid promeretur dici rex, si semper habeatur exlex? Quia legem Dei nec tenet, nec tuetur. Et quia non timet Deum, timebit quidem hominem inimicum suum. Adulter est, vel perjurus, sive sacrilegus; hic talis nomen regis perdit." 


\section{Leader in War}

Fulcher's narrative is militant in tone, focusing overtly at times on the nature of battles and conquests, several of which he experienced in person. He could have chosen to focus on the political decisions and peaceful periods to fully develop the history of Baldwin, but did not. Instead the chaplain focuses on the king's valor, giving due justice to his claim that Baldwin was the shield, strength and protector of his people. This account had a dual purpose for Fulcher's audience. Here was the king at his best, as a leader in the field and generally striking his enemies with fear and admiration.

Constantly outnumbered, the king strikes back against staggering odds with the power of the almighty as did Joshua. In his praise over the victory at Dog River, Fulcher waxes eloquent in his reminder to his readers that with God on the side of the crusaders; nothing is impossible:

Oh how admirable are the works of God! Oh how very miraculous and how worthy of remembrance! We had been conquered but from being conquered we became conquerors. But we ourselves did not conquer. How, therefore, did we not conquer? He conquered who alone is the omnipotent Creator of all, in compassion for His creatures aiding Him. "If God be for us, who can be against us?" [Rom. 8:31]. Truly for us, and with us, and in us was fulfilled what He said through the prophet to the Isrealites, "If you shall have obeyed my laws I shall enrich you with this gift, that five of you shall succeed against one hundred of the enemy, and one hundred of you against ten thousand!" [Levit. 26:8]. And because we endured much suffering day and night in His service, and trusted no one else, He wondrously broke the pride of the enemy. And because we served the Lord with devout hearts in tribulation, He hath regard for our humility. ${ }^{186}$

Fulcher was deliberately painting a portrait of Christian victory for his readers,

186 FC, 141; RHC Oc. 376, “O quam admirabilia Dei facta! o quam magnum miraculum, et memoriae digniter commendandum! Victi eramus, et victi vicimus, sed nos non vicimus. Quomodo ergo non vicimus? Vicit enim ille qui solus est omnipotens Creator omnium, creaturae suae pie subveniens. Quod si Deus pro nobis, quis contra nos? Vere pro nobis et nobiscum fuit, complens in nobis quod Israeliticis per prophetam dixit: Si preecepta mea servaveritis; hoc dono vos ditabo, ut persequantur quinque de vobis centum alienos, et centum ex vobis decem millia. Et quia in Dei servitio laborem multimodum die ac nocte tolerabamus, et in nullo alio confidebamus, superbiam corum magnifice cassavit. Et quia devote et in tribulato corde Domino famulabamur, humilitatem nostram respexit." 
highlighting that the events that really mattered were currently happening in Palestine. The occasional military losses were attributed to grave sins, as all the chroniclers agreed. Like the Israelites' crime of taking goods from the defeated city of Ai against the direct order of God to destroy the plunder, on occasion the crusaders too were known to indulge in sinful conduct, for which they were punished. ${ }^{187}$ Fulcher tends to focus on the grand encounters between the west and the east, and it is rare to see the chaplain recording small skirmishes unless there is a salient point to be brought forth, such as the death of someone important, like William-Jordan. Fulcher understood the conflict between the Franks and the Muslim communities to mark an epoch in world and biblical history, and thus his writing portrays a heroic element to its composition.

Fulcher purposefully depicts Baldwin as the senior character in every battle that truly mattered, including the sieges of the coastal cities. The capture of Sidon for example, made possible by the assistance of the king of Norway, is still rendered as a Baldwin-centered affair. Sigurd Magnuson gets barely a mention as leading the fleet of Norwegians, and if Fulcher was the only source available to the historian, one might imagine Sigurd sitting around in Jerusalem while his troops fought bravely for Baldwin. Likewise, the Venetian fleet that arrived in time to ward off the Egyptian relief force is not even given mention for their role in saving the rearguard of the Norwegian fleet. Two major allies had been utilized by the king of Jerusalem to take the city, but Fulcher allows them to fall in the shadow of Baldwin's glory, an omission that is unjustified unless the chaplain felt that they were really auxiliary in nature, though the comparative record of the battle shows that they were indeed instrumental. ${ }^{188}$ Again, during the battles that took 
place near Ramleh, although Baldwin nearly lost the first battle, and did on the second time the Egyptians invaded, the king remains a romantic leader. One might argue that this is because Fulcher's narrative is really a heroic history, detailing the deeds of just one man to the exclusion of others, but in fact the chaplain shapes his history to suggest the fact that no one else was responsible ultimately for victory or failure other than the king. As God's chosen leader of the kingdom, the king makes the decisions and according to Fulcher, is the target of rebuke by his allies for his failures to wait for reinforcements on at least two occasions. ${ }^{189}$

One last commentary on kingship that Fulcher makes without being explicit, is that the kingdom's security rests on just one man, the king. Fearing the death of Baldwin after one battle in 1101, the citizens of Joppa appealed to Tancred in Antioch to come to their aid. Contemporaries understood that the kingdom was in peril without a strong leader and they made the choice that seemed best in the situation. ${ }^{190}$ This inherent weakness in the available leadership and security of the kingdom is not commented on by Fulcher, perhaps because of his ability to look back at the generally successful history of Baldwin after the king's death in 1118. However, I would argue that the chaplain did not really doubt the outcome of events during their occurrences, thanks primarily to his fluid citations of scriptural reference throughout his narrative. Unlike William of Tyre or Albert of Aachen, Fulcher is often prone to point out the intervention of God in his history by way of explanation for the outcomes of battles and moments of crisis for the kingdom. Fulcher sees the Biblical narrative as being woven into the history of the crusades, and for him the strategic risks of placing the kingdom's security always on one 189 FC, 168, 206-207.

190 FC, 160-163. 
man does not cause him concern. The very success of the enterprise is rather proof of God's blessing and anointing of a second Joshua for His people, rather than a tenuous strategic bluff that Baldwin often engaged in. God did not have to stop the sun in the sky as was done for Joshua, or Charlemagne in the Song of Roland, because the blessing for successful conquest and the military power of the armored knight had already been given. ${ }^{191}$

\section{Fair in Rule}

Fulcher makes the comment twice in his narrative, once for Baldwin and once for Baldwin of Bourcq who succeeded him, that a king who does not protect his people is not worthy to rule over them. The first mention of this point of view comes at the beginning of Baldwin's reign, when Fulcher assesses the state of the kingdom and narrates the adventures of the king. ${ }^{192}$ The second occurrence comes after the capture of Baldwin II and Fulcher's scathing commentary on the king's failure to heed the dangers to his person, jeopardizing the fate of the kingdom because of his capture and incarceration. ${ }^{193}$ These episodes indicate that the chaplain had certain expectations of Baldwin's monarchy; but where does he get the example?

In addressing the issue of famous royal predecessors, Baldwin's kingship is not compared to King David. In fact, no king of Israel or Judah from the Old Testament gets compared to Baldwin in the chronicle. Rather it would seem that as a defender of his people by aggression against the enemy, Baldwin gets the praise of being a noble ruler in

\footnotetext{
191 Joshua 10:12-15

192 FC, 148-149.

193 FC, 245-246.
} 
a class by himself. He is a conqueror more than a bureaucratic leader, giving orders and expecting to be obeyed. Only Moses and Joshua fit this mold of early biblical leader, and thus it makes perfect sense that Fulcher would promote the similarity. Only on the occasions when Baldwin did not wait for reinforcements, such as the Second Battle of Ramleh, did Fulcher rebuke him. However, there were no other complaints arising from the people about Baldwin's conduct or leadership, according to Fulcher.

Fulcher portrays the ecclesiastical and lay leaders as being completely behind the king in all his decisions, both supportive as well as ready to respond to the king's commands to come or go as the situation dictates. Is this just royalist propaganda? The answer is no, when compared with the accounts of William of Tyre and Albert of Aachen. Although the former is also a royalist writer and tends to defend the king, William focuses on the benefits to the kingdom and the establishment of a just monarchy under Baldwin. Albert of Aachen gives more details when dealing with the king's ruthlessness against opposition and the ever present quest for money, but likewise gives Baldwin a positive review regarding his kingship.

As a counterpoint, the barons of the realm get very little in the way of a voice in the narrative of Fulcher, being neither present in the decision of the king to marry Adelaide, in which case he probably did not ask, or in his decision to divorce her. Prefacing the marriage as one in which Baldwin was pursuing a hefty dowry, Fulcher uses the king's later illness as a means to comment on the immorality of the monarch and the judgment of God. Baldwin's decision to repudiate his third wife was not governed by the concern of his vassals over the fact that his death would leave Roger II of Sicily as 
their king. ${ }^{194}$ This is the idea asserted by the chaplain, and it is important because it supports the notion that the king was subject to no one but God in this matter, and thus master and commander of his kingdom in relation to the nobility.

To further illustrate this point, one needs only to look back at the succession of Baldwin II to the throne. Fulcher never demonstrates in his narrative the concern of the barons for who will actually rule them next at the death of the king. His only clue is found at the start of Book III, in which he makes the point that Baldwin of Bourcq arrived in Jerusalem to confer with the king, and was then unanimously elected by the people lest they appear weak to the enemy around them for not having a monarch on the throne. Fulcher does not state that the question of the succession was to be discussed, but leaves the hint by not focusing too unduly on Baldwin of Bourcq's timing. He was in Jerusalem for the Easter celebration within days of Baldwin I's death, and this could have been nothing if not "providential.""195

On this issue Albert of Aachen supports the point that the vassals were confident in Baldwin's decisions and suggestions for who would be his successor, illustrated by a short speech in which he upbraids the people for their fear and suggests Eustace his brother and Baldwin of Bourcq. Interestingly, this short scene recorded by Albert is very similar to the closing episode of the Biblical book of Joshua, in which the aged leader gives the people some final instructions as death was approaching:

Having said this, Baldwin, a man who was the noblest of noble blood in his native land of Lotharingia, most splendid and victorious king in the kingdom of Jerusalem, most valiant champion of God, breathed his last, steadfast in the faith of Christ and purified by confession, and fortified by partaking of the Lord's body

\footnotetext{
194 FC, 217-218.
}

195 FC, 222-226. 
and blood. 196

Thus the final chapter of Baldwin's life closes with the "good death," having been denied that of a heroic martyr in battle, he exits the stage at peace with God and men. ${ }^{197}$

His obvious reluctance to comment on potentially divisive and factional concerns, demonstrates Fulcher's attempt to show the end of Baldwin's reign to be as graceful as the beginning. Christians behaving poorly at the end, arguing over who should take the physical reins of the kingdom, might not have reflected well on Christianity as a whole to the western readership. Instead, true to the image he painted, Fulcher shows friend and foe alike mourning the departing king, as a new Joshua leaving the kingdom he had worked so hard to create, beloved by the people and respected by his enemies:

At the sight of this and as if Baldwin were a kinsman, all who were present gave themselves over to mourning rather than song, to grief rather than joy. The Franks wept, the Syrians, and even the Saracens who saw it grieved also. For who could contain himself? Who there did not weep piously? ${ }^{198}$

\section{The Tolerant King}

What is not so clear according to the chaplain's narrative is his feeling on the relationship of the king towards the subjected people under his rule, peace agreements with the enemy, and the settlement of Syrian Christians in Jerusalem. As much as Fulcher is reluctant to focus on the weakness of the kingdom's army and its defenses, Baldwin is generally portrayed as a leader dictating terms from a position of

\footnotetext{
196 AA, 869. "Et hoc dicto, uir in terra natiuitatis sue de Lotharingia ex nobili sanguine nobilissimus, rex in regno Ierusalem gloriosissimus ac uictoriosissimus, Dei athleta fortissimus, spiritum uite exalauit, in fide Christi stabilis et in confessione purgatus, et dominici corporis et sanguinis perceptione munitus." Joshua 23:1 - 24:33.

197 Paul Binski, Medieval Death: Ritual and Representation (Ithaca: Cornell University Press, 1996), 33-50.

198 FC, 222; RHC Oc. 436, "Quo viso, et sicut erat cognito, pro cantu luctum, pro laetitia gemitum, cuncti qui aderant dederunt. Plorant Franci, lugent Syri, et qui hoc videbant Sarraceni. Quis enim se continere posset, qui non ibi pie fleret?"
} 
strength. This is important because it justifies arguments of mercy and toleration on the part of the king without having to sacrifice his image, namely to admit that Baldwin often had a weaker bargaining position and had to accept demands from his allies as well as some negotiation with his enemies.

Although tending to focus on the king's attempt to ransom powerful men for their wealth, after a successful siege of a city or a raid, Fulcher does not typically show the economic side of a dispute. Depicting a Christian releasing a "pagan" for monetary gain would seem counter productive to the prosecution of the crusades at a fundamental level. On one occasion though, the chaplain laments that Baldwin had failed to capture a particularly valuable leader of the Egyptian army, but then contents himself with the fact that the king did slay the second-in-command and ransomed a local potentate:

Oh if Semelmulc, the commander of their army, could have been captured, how much money might have been paid for his ransom to King Baldwin! But Gemelmulc, the Amir of Ascalon and a very rich man, did not escape. He was slain, which caused no little desolation among those people. Another amir, formerly of Acre, was captured alive. Our king caused him to be ransomed for twenty thousand pieces of money besides horses and other things. ${ }^{199}$

In addition to the financially beneficial captures such as these, Fulcher would have his readers view the king as merciful towards those that approached his banner and submitted to his rule. While the Italians and Bertrand of Tripoli are shown willing to slaughter the Muslim and Jewish communities in the coastal cities, the king holds out the opportunity for safety to anyone who seeks his protection. As mentioned earlier, the actual position of Baldwin in relation to his allies may have been much weaker than is

199 FC, 186-187; RHC Oc. 414, “O si capi potuisset Semelmul, dux illius militiae, multa nummismata in redemptionem sui regi Balduino exsolveret. Sed non effugit Gemelmule admiratus Ascalonae, qui locuples erat valde. Quo interempto, illis omnibus orta est non minima desolatio. Alterum admiraldum olim Acconitam vivum retinuerunt, quem rex noster redimi fecit viginti millibus nummismatibus, praeter equos et res alias." 
portrayed by Fulcher, but the point is that he admires the nobility of Baldwin, and his practical if not altruistic humanity. Subject people only enhanced Baldwin's authority, and the wealth of the kingdom. Fulcher tends to portray the king and his role as monarch of Jerusalem as above mere earthly motivations, because the battle is one between good and evil, as evidenced by his use of the Psalms to eulogize the defeat of the Fatimid army following the Third Battle of Ramla:

Then we praised and glorified God in whom we found great strength and who brought our enemies to destruction [Psalm 59:14]. Oh wonderful decree of divine judgment! Behold those who said: "'We shall come and kill all those Christians and we shall possess their holy places' [Psalm 82:13]. But it did not happen thus, oh infidels, not thus" [Psalm 1:4] because "God made you like a whirling dust, like chaff before the wind [Psalm 82:14] so that He might terrify you in His fury" [Psalm 2:5]. ${ }^{200}$

The agreement with Damascus later in Baldwin's reign, after Toghtekin sought a peaceful truce with Baldwin in 1108, receives neither positive nor negative commentary from the chaplain. Toghtekin was compromised due to his involvement in the murder of Mandūd of Mosul, and thus sought a friend in the Christians. ${ }^{201}$ Fulcher fails to mention that this important bit of diplomacy, though tested sorely at times by both parties, was of great benefit to securing the kingdom against a potentially dangerous enemy in the northeast. The peace treaty was made for ten years, but it was in fact to last right up to the Second Crusade and the disastrous political blunder of Conrad II and Louis VII, who engaged in a failed attempt to take Damascus. ${ }^{202}$ During Baldwin's rule, acceptance of

200 FC, 187; RHC Oc. 414, “Tunc Deus laudatur, glorificatur, in quo virtutem fecimus magnam, qui etiam ad nihilum deduxit inimicos nostros. O mira divini judicii ordinatio! Ecce qui dicebant: Eamus, et Christianos omnes illos occidamus, et possidebimus corum sanctuarium. Sed non sic impii, non sic : quia vos posuit Deus ut rotam, et sicut stipulam ante faciem venti in ira sua vos confudit. In lege sua juraverant etiam ipsi nunquam propter Francos fugere; sed tandem effugium salus fuit tunc eorum. Maluerunt perjurium incurrere, quam morte stulte perire."

201 FC, 211.

202 Jonathan Phillip, The Crusades 1095-1197 (New York: Longman Publishing, 2002), 75-76. 
peace is revealed by Fulcher to be an act of clemency on the part of the king with the interest of his people foremost in his mind. It appears that the chaplain cannot be completely forthright in his interpretation of events. He does not reveal the fact that Baldwin lacked sufficient forces at the moment to attempt an attack during the political weakness of the Damascus leadership, and that a loss if he had tried would have left the kingdom wide open to attack from its Egyptian opponents.

Here the historian must conjecture that Fulcher was again trying to paint Baldwin in the best light, and hypothesizing that in the future the king might still take battle to his northern enemies. For the moment, Fulcher's Joshua was resting after so much beneficial conflict, leaving the rest of the 'promised land' to wait for its eventual conquest. ${ }^{203}$ It is true that at the death of the Joshua the Israelite leader, the land had not been fully conquered and he had certain admonitions to give the people he was leaving. He stressed that they needed to finish the job and focused on the fact that one man among them could drive off a thousand, a promise which was seen to have particular resonance with Fulcher and his understanding of the crusader cause..$^{204}$

Fulcher's redaction of the material in 1124 concludes his account, and he was probably satisfied with the portrayal he left, several years after the death of the king. This no doubt tied into his revealing commentary on the nature of the inhabitants of Palestine, and the change of identification that Europeans had experienced, tying their identities and self definition to the lands they now inhabited:

For we who were Occidentals have now become Orientals. He who was a Roman or a Frank has in this land been made into a Galilean or a Palestinian. He who was of Rheims or Chartres has now become a citizen of Tyre or Antioch.

\footnotetext{
203 Joshua 13:1-7

204 Joshua 23:1-13; FC, 141.
} 
We have already forgotten the places of our birth; already these are unknown to many of us or not mentioned any more. ${ }^{205}$

Fulcher did feel that he was living in a post-Joshua Israel, largely conquered and taken over by the westerners, and a situation which he might assume was to last until the Second Coming of Christ.

The repopulating of Jerusalem with Syrian Christians was probably a strange account for the chaplain to write in light of his purely pro-Frankish argument. Fulcher makes the sudden point in his narrative about the king's decision: that the holy city which appeared to be the heart and center of the kingdom, was actually at most populated on only one street. There simply had not been enough colonizers from the west to raise the city back to its former population level, and with little explanation, Fulcher leaves his readers with the impression that Jerusalem is a ghost town dominated in one corner by the king and the patriarch, who had taken up residence in the best section they could find. Was this really the situation, or did the chaplain exaggerate to explain his master's move in inviting natives of the east, who had not been permitted to inhabit the city in any great numbers before, to suddenly taking up residence wherever they would like?

The answer seems to lie somewhere in between. As much as the narrative suggests that Baldwin was inviting Christian brothers and sisters to join his people, the basic attraction the native people provide is in the usefulness of their manpower and economic support for the kingdom. One is reminded in Fulcher's telling of the episode, of the Gibeonites who 'trick' the Israelite army in the Biblical book of Joshua. They were successful in pretending to be from a far distant land, and secured an agreement of peace

${ }^{205}$ FC, 271; RHC Oc. 468, "Nam qui fuimus occidentales, nunc facti sumus orientales. Qui fuit Romanus aut Francus, hac in terra factus est Galilaeus, aut Palaestinus. Qui fuit Remensis aut Carnotensis, nunc efficitur Tyrius vel Antiochenus. Jam obliti sumus nativitatis nostrae loca; jam nobis pluribus vel sunt ignota, vet etiam inaudita." 
before their new allies discovered that they were locals. When this fact was discovered the Children of Israel were more than a little upset, but they stood by the agreement, modifying it to make the Gibeonites subservient and carriers of water and woodsmen for the people of Israel. The diplomatic agreement was not sanctioned for the Israelites to make in light of their command by God to drive out or to eliminate the people already settled in Palestine, but it did secure the survival of the Gibeonites. ${ }^{206}$

Thus it would seem that in this case, Fulcher was a little embarrassed by the decision of Baldwin to invite into Jerusalem outsiders that had not recognized the Latin Church beforehand. Making the best of it, the chaplain highlighted the poverty of inhabitants in order to justify Baldwin as a Christian king and a crusader, bringing people into the holy city where previously almost everyone had been expelled following the conquest in 1099. Fulcher is very vague about where these new settlers came from, simply saying that Baldwin looked about for potential residents and found some that were being persecuted by their Muslim overlords. That was good enough for Baldwin, and they were thus given an invitation to relocate to Jerusalem.

\section{Conclusion}

Looking at Fulcher's narrative of the First Crusade and the reign of Baldwin, the basic argument of his history emerges quite plainly: that the crusaders were the spiritual inheritors of the Israelites and therefore promised a home in Palestine by God. This was not necessarily the initial feeling of the crusaders or the reason they had set out in the first place, but an adapted idea as events unfolded. The first phase of the conquest took place

\footnotetext{
206 Joshua 9:1-27.
} 
under Godfrey, when the people entered the promised land. With Godfrey's death, the Moses that had led the people was removed from the scene to be eclipsed by a new Joshua that would actually begin the work of consolidation and conquest. The very success of Baldwin, though often dependent on a measure of good fortune (if not divine aid, as Fulcher would have seen it), were enough to secure such a reputation for the king in the eyes of his biographer and contemporaries.

It would appear that at times Fulcher purposefully shapes his narrative to place the king in the best possible light, suppressing important information that he should have known, given that he was Baldwin's confessor. However frustrating this might be to present day scholars, Fulcher's answer would be that it did not serve the point of his writing, which was to demonstrate to his readers that God was doing a marvelous work again in the land of His special favor. This time He was using the Franks and all of western Christendom to prepare the way for the Second Coming. The third phase of the chaplain's history confirms this in the relatively settled kingdom, ruled by Baldwin II. In these final years of Fulcher's life, he relates his famous commentary on the establishment of a new cultural basis for the colonizers of the holy land, and notes the change in identity that had caused them to forget the lands of their birth. In his late sixties, having spent more than half of his life in the east, it is easy to see that this was Fulcher's understanding of the historically significant events that he had experienced firsthand. ${ }^{207}$

Thus the epitaph that Fulcher wrote for Baldwin, highlighting the king's role as a shield, the strength, and the support of his people, was fully justified to the chaplain. His failure to point out that Baldwin sometimes made compromising choices to sustain this

207 FC, 271-272. 
role was irrelevant to Fulcher as long as the end result was achieved. Fulcher is then both a controversial authority on the nature of Baldwin, as well as an eyewitness source, unlike other crusader histories available from the twelfth century. His hero worshiping, claiming Baldwin as a second Joshua, is validated by his own point of view. Fulcher realized the truth that while the crusaders won the city, Baldwin alone created the kingdom. Leadership had not been missing from the First Crusade, but it was strong directive leadership after the initial success that was needed to see the conquest to its potential conclusion.

Most importantly, the Joshua comparison, though perhaps espoused during the life of Baldwin, was not for the king's benefit. At every crucial juncture of the First Crusade, there was a moment when the question was raised: what to do next? The most controversial point was the post-victory naming of a ruler for Jerusalem. The second had been the crisis of holding onto the kingdom with the death of Godfrey. For Fulcher, the third great crisis was the death of Baldwin, a morale sinking event that had to be combated. Baldwin had done more of permanent benefit to the kingdom than any other leader, and his act would be a hard one to follow. Thus his life, deeds, and final passing had to be identified with someone whose memory promised continued permanence, such as the biblical figure of Joshua. The epitaph of Baldwin was not just the praise of a leader whom they had lost, but a reminder that God had done truly amazing things for the crusaders by giving them such a leader, and promising that continued support would be forthcoming under their next king. The kingdom would survive because God had made it so under His second Joshua, and thus it was not time to abandon the holy land, but to 
hold fast and continue the work of Baldwin I. 


\section{Chapter 5 - Conclusion}

In the preceding chapters the life and actions of Baldwin, first king of Jerusalem, have been examined in some detail. The question of whether or not he deserved to be recognized as instrumental to the founding of the Latin Kingdom and its prosperity in the final tally, can be answered positively. This is not a different interpretation from the current scholarship of eminent authorities on the crusader kings such as Hans Ebehard Meyer, Steven Runciman, or Alan V. Murray. The addition of coastal cities and the organization of the Latin principalities such as Jerusalem and Tripoli in defense of their new territories has always been ascribed to Baldwin, as has the reintroduction of eastern Christians to the holy city. Establishing the kingdom as a major player in the political scene of the Middle East was Baldwin's contribution as well, a position he utilized effectively to pursue a moderate state of war with his enemies, never tipping the scale too far when the fate of the kingdom was in the balance. In a simple sentence: Baldwin was an effective ruler and respected as such.

The reinterpretation I have sought to bring to light utilizing the work of Fulcher of Chartres in particular as a primary source, is that Baldwin still bears close examination as a pertinent historical figure in the early chapters of the Christian occupation of Palestine. The memories of Fulcher the chaplain, which preserves a biography of Baldwin in the second book of his famous history, left the world with an interpretation that saw the king as a great Christian leader ordained and anointed by God. Taking the historical events that he often witnessed firsthand, Fulcher left an account that shaped Baldwin's 
story in parallel with the Jewish figure and biblical hero, Joshua. While not outright falsifying the events in his text that detracted from the main comparisons between these two men, it is clear from other writers that Fulcher downplayed other actions of his king. Yet, Fulcher steeped in biblical tradition, saw the parallel ways in which these two men, biblical and contemporary, seemed to follow a fairly similar path for God's people. For a man versed in the Old Testament scriptures as he demonstrates throughout his history, the comparison was a forgone conclusion. Fulcher clearly wanted Baldwin to be remembered in the west as well as the east, as the man who created the kingdom while leading his people in the only way he could if he wanted to succeed, as a Biblical archetype anticipating the end of time and the Second Coming of Christ.

While Fulcher's work is helpful in demonstrating medieval memory of kings in the east, and particularly of Baldwin, the facts also demonstrate that Baldwin was amazingly fortunate at times throughout his eighteen long years of rule. The Italian merchant cities were indispensable to the survival of the Latin Kingdom. The timely arrival of annual pilgrimages was another bonus to Baldwin's tenuous campaigns, which often depended heavily upon their continued support, and the unexpected arrival of the Norwegians under Sigurd was most certainly perceived as a miracle. Add to these strokes of luck Baldwin's occupation of Edessa with almost no effort on his part, and one must walk away feeling that Baldwin was in many respects like his contemporary El Cid, another successful soldier of fortune who got many breaks in spite of desperate opposition.

However, as also demonstrated in this work, Baldwin was not so undeserving of 
his position, as the residents of the Latin Kingdom could testify. While sometimes prone to rash actions and feats of bravado that got him in trouble and led to flight from the enemy, on the whole the king knew how to turn events to his advantage. Baldwin had a mind for negotiation, and utilized the language of diplomacy that was in no small way owing to his early education for an ecclesiastical career. The ability to keep all of his contemporary leaders at bay while hanging onto the crown, his manipulation of the patriarchy of Jerusalem for his own ends, and the choice even at the end of his own successor, depict a man who was fully in control of his temporal inheritance. In this light, Fulcher of Chartres was not far wrong in displaying for the world his hero as a powerful leader. With the odds stacked against him, any success would have been seen as providential, but Baldwin was also responsible for his growing reputation while restlessly pursuing his goals.

If there is a lesson to be learned from the career of the king, it would seem to lie in the fact that he utilized effective management skills in combination with a certain amount of risk taking. If he was not happy with the men he placed in positions of power, he changed them and continued to do so until he found an effective working associate. This was the case with the patriarchate of Jerusalem. Practical rather than dogmatic, he knew how and when to veer away from popular opinion when it had economic benefit, such as maintaining the Greek priests in Jerusalem, or inviting in the Syrian Christians. Finally, he embraced the notion that fortune, or God, favored the bold, pressing his acquisitional potential until it failed him. In many ways Baldwin would have made an excellent corporate leader in the modern world, and can still teach us. 
In closing I must argue that Baldwin, like so many others of his crusading contemporaries, was far from being a ragamuffin petty lord, part of a useless glut of medieval overpopulation siphoned off to the east. Jonathan Riley-Smith argues that "quality clergy" were far under-represented in the Palestine, but I would argue that the flower of the west had gone on the great adventure of their time, and like many of their later descendants, the Lord Edward of England being just one famous character, they were men of great talent and potential. Baldwin I of Jerusalem was rightly deserving of Fulcher's epitaph for him, as a second Joshua that faithfully led and defended his people. It would be to the benefit to the medieval studies of Europe, Asia, and Africa if historians focused more attention on the crusader period, for the heritage of the west was changed in no small way by their outcome, to say nothing of the east. The strength of modern Christian and Islamic tradition still rests on the reinforcement given to both sides during this chapter of conflict, and a lesson of understanding between the two positions can be gained by a thorough study of the men and women who participated in the crusader period. 


\section{Bibliography}

Albert of Aachen. Historia Ierosolimitana: History of the Journey to Jerusalem. Translated by Susan Edgington. Oxford: Oxford University Press, 2007.

Barber, Malcolm. The Crusader States. London: Yale University Press, 2012.

Binski, Paul. Medieval Death: Ritual and Representation. Ithaca: Cornell University Press, 1996.

Bisson, Thomas. The Crisis of the Twelfth Century: Power, Lordship, and the Origin of European Government. Princeton: Princeton University Press, 2009.

Bull, Marcus. Knightly Piety and the Lay Response to the First Crusade: the Limousin and Gascony, c.950-c.1130. Oxford: Oxford University Press, 1993.

Edbury, Peter W., and John Gordon Rowe. William of Tyre: Historian of the Latin East. Cambridge: Cambridge University Press, 1988.

Ellenblum, Ronnie. Frankish Rural Settlement in the Latin Kingdom of Jerusalem. Cambridge: Cambridge University Press, 1998.

Epp, Verena. Fulcher von Chartres. Studien zur Geschichtsschreibung des ersten Kreuzzuges. Düsseldorf: Droste Verlag, 1990.

France, John. Victory in the East: A Military History of the First Crusade. Cambridge: Cambridge University Press, 1994.

Fröhlich, Walter. The Letters of Saint Anselm of Canterbury. Vol. 3. Kalamazoo: Cistercian Publications, 1994.

Fulcher of Chartres. A History of the Expedition to Jerusalem 1095-1127. Translated by Frances Rita Ryan. Edited by Harold S. Fink. Knoxville: University of Tennessee Press, 1969.

Gabriele, Matthew. An Empire of Memory: The Legend of Charlemagne, the Franks, and Jerusalem before the First Crusade. Oxford: Oxford University Press, 2011.

Gaposchkin, M.C. "Louis IX, Crusade and the Promise of Joshua in the Holy Land." Journal of Medieval Studies, Vol. 34, (2008): 245-274. 
Guibert of Nogent. The Deeds of God through the Franks. Translated by Robert Levine. New York: Boydell Press, 1997.

Hamilton, Bernard. The Latin Church in the Crusader State: The Secular Church. London: Variorum Publications, 1980.

Hill, John H., and Laurita L. Hill. Raymond the IV: Count of Toulouse. Syracuse: Syracuse University Press, 1962.

Housley, Norman. Fighting for the Cross: Crusading to the Holy Land. London: Yale University Press, 2008.

Matthew, Donald. The Norman Kingdom of Sicily. Cambridge: Cambridge University Press, 1992.

Mayer, Hans Eberhard. The Crusades. Translated by John Gillingham. London: Oxford University Press, 1972.

---, and Jean Richard, eds. Die Urkunden der lateinischen Könige von Jerusalem. 4 vols. Hannover: Hahnsche Buchhandlung, 2010.

Moore, R.I. The Formation of a Persecuting Society: Power and Deviance in Western Europe, 950-1250. Oxford: Blackwell Publishers, 1987.

Munro, Dana. “A Crusader.” Speculum, Vol.7, No.3 (1932): 321-335.

Murray, Alan V. "Daimbert of Pisa, the Domus Godefridi and the Assencion of Baldwin I of Jerusalem." From Clermont to Jerusalem: The Crusades and Crusader Societies, 1095-1500. ed. Alan V. Murray. Turnhout: Brepols, 1998.

---. The Crusader Kingdom of Jerusalem: A Dynastic History 1099-1125. Oxford: Prosopographica et Genealogia, 2000.

Nicholson, Robert Lawrence. Joscelyn I, Prince of Edessa. Urbana: University of Illinois Press, 1954.

Norwich, John Julius. The History of Venice. New York: Borzoi Books, 1982.

Phillips, Jonathan. The Crusades 1095-1197. New York: Longman Publishing, 2002.

---. The Second Crusade: Extending the Frontiers of Christendom. London: Yale University Press, 2007.

Prawer, Joshua. Crusader Institutions. Oxford: Oxford University Press, 1980. 
---. The Crusader's Kingdom: European Colonialism in the Middle Ages. New York: Praeger Publishers, 1972.

Ralph of Caen. Gesta Tancredi. Translated by Bernard S. Bachrach and David S. Bachrach. Aldershot: Ashgate Publishing, 2005.

Riley-Smith, Jonathan. Crusades, Christianity, and Islam. New York: Columbia University Press, 2008.

---. The Crusades: A History. London: Yale Nota Bene, 2005.

---. The First Crusaders. Oxford: Oxford University Press, 1993.

---. "The Latin Clergy and the Settlement in Palestine and Syria, 1098-1100." The Catholic Historical Review 74 (October 1988): 539-557.

Robert of Reims. Robert the Monk's History of the First Crusade: Historia Iherosolimitana. Translated by Carol Sweetenham. Aldershot: Ashgate Publishing, 2006.

Rowe, John G. "Paschal II and the Relation between the Spiritual and Temporal Powers in the Kingdom of Jerusalem." Speculum, Vol.32, No.3 (1957): 470501.

Rubenstein, Jay. Armies of Heaven: The First Crusade and the Quest for Apocalypse. New York: Basic Books, 2011.

Runciman, Steven. A History of the Crusades. Vol. 2, The Kingdom of Jerusalem and the Frankish East 1100-1187. Cambridge: Cambridge University Press, 1954.

Schein, Sylvia. Gateway to the Heavenly City: Crusader Jerusalem and the Catholic West (1099-1187). Aldershot: Ashgate Publishing, 2005.

Smail, R.C. Crusading Warefare 1097-1193. Cambridge: Cambridge University Press, 1995.

Snorri Sturluson. Heimskringla. In Early Travels in Palestine, ed. Thomas Wright. New York: KTAV Publishing, 1968.

Tyerman, Christopher. The Debate on the Crusades. Manchester: Manchester University Press, 2011.

---. God's War: A New History of the Crusades. Cambridge: Belknap Press, 2006. 
William the Chancellor. The Antiochene Wars. Translated by Thomas S. Ashbridge and Susan B. Edgington. Brookfield: Ashgate Publishing, 1999.

William of Tyre. A History of Deeds Done Beyond the Sea. Translated by Emily Atwater Babcock and A.C. Krey. 2 vols. New York: Octagon Books, 1976. 